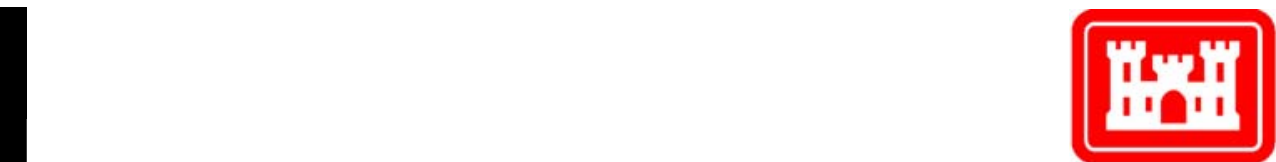

US Army Corps of Engineers 。

Engineer Research and Development Center

\title{
Sustainable Design and Development Charrette for U.S. Army Military Installations in the Korean Peninsula
}

Chang W. Sohn, Annette L. Stumpf, Roch A. Ducey, and Chris Kim 


\section{Foreword}

This study was conducted for the Far East District (FED), U.S. Army Corps of Engineers (USACE), under Reimbursable Order No. WT4KCL-20394184, "SDD Charrette at FED," Task CFE-G42. The FED technical monitor was Chris Kim, CEPOF-ED-DA.

The work was performed by the Energy Branch (CF-E) and the Engineering Processes Branch (CF-N) of the Facilities Division (CF), Construction Engineering Research Laboratory (CERL). The CERL Principal Investigators were Dr. Chang W. Sohn, Roch Ducey, and Annette Stumpf. Assistance from Directorate of Public Works staff at Camp Casey and Yongsan Post was critical in understanding the local characteristics and is greatly appreciated. Dr. Tom Hartranft is Chief, CEERD-CF-E; Donald Hicks is Chief, CEERD-CF-N; and L. Michael Golish is Chief, CEERD-CF. The technical editor was William J. Wolfe, Information Technology Laboratory. The associated Technical Director is Dr. Paul Howdyshell, CEERD-CV-T. The Director of CERL is Dr. Alan W. Moore.

CERL is an element of the U.S. Army Engineer Research and Development Center (ERDC), U.S. Army Corps of Engineers. The Commander and Executive Director of ERDC is COL John W. Morris III, EN, and the Director of ERDC is Dr. James R. Houston.

DISCLAIMER: The contents of this report are not to be used for advertising, publication, or promotional purposes. Citation of trade names does not constitute an official endorsement or approval of the use of such commercial products. All product names and trademarks cited are the property of their respective owners. The findings of this report are not to be construed as an official Department of the Army position unless so designated by other authorized documents. 


\section{Contents}

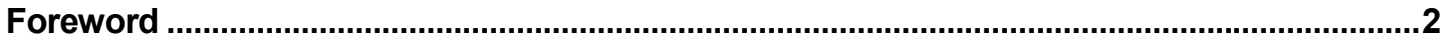

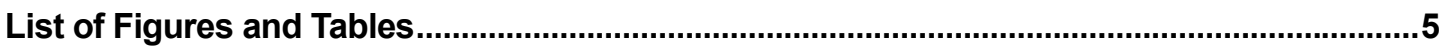

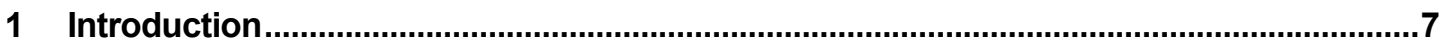

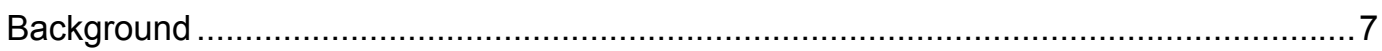

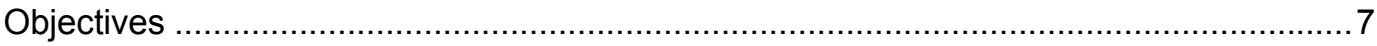

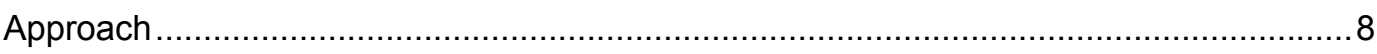

Scope

Mode of Technology Transfer......................................................................... 10

2 Sustainable Design and Development Charrette at FED ..............................................11

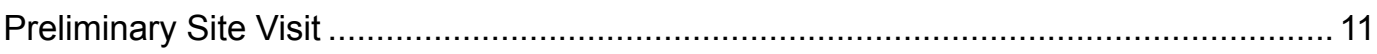

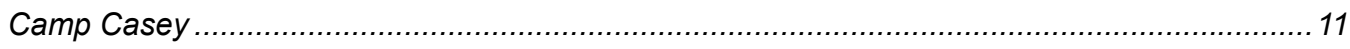

Yongsan Post

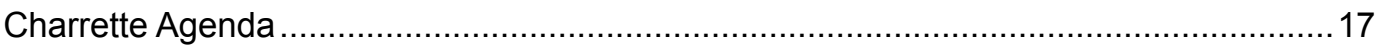

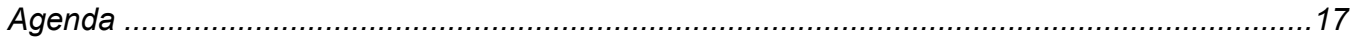

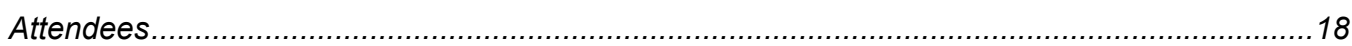

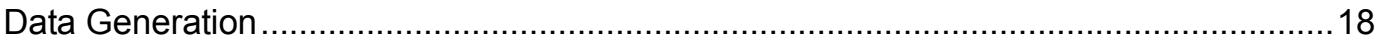

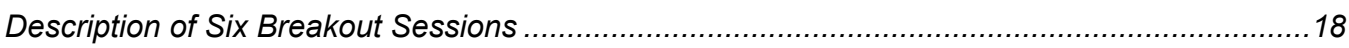

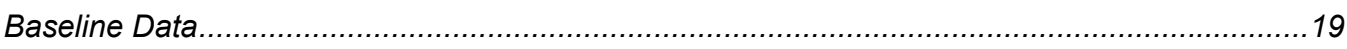

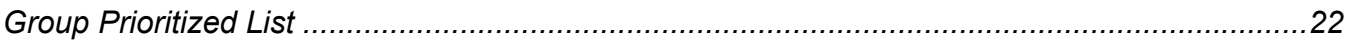

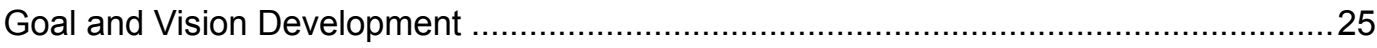

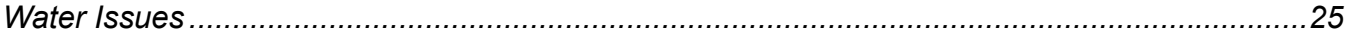

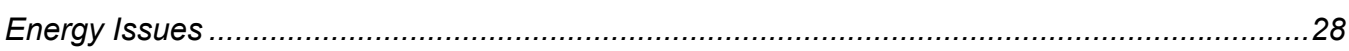

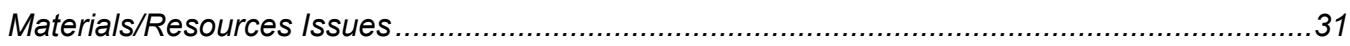

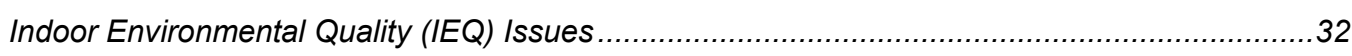

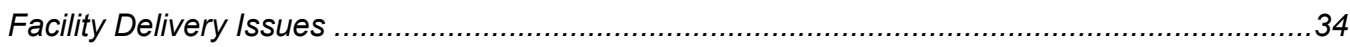

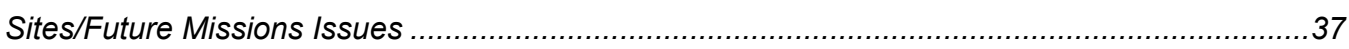

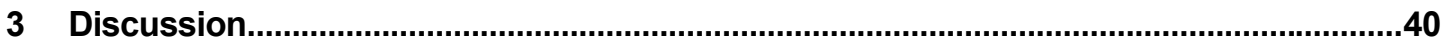

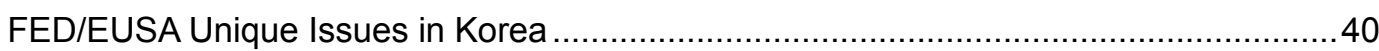

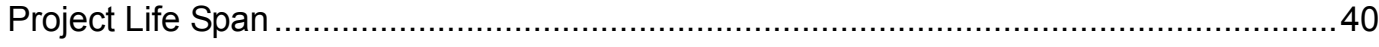

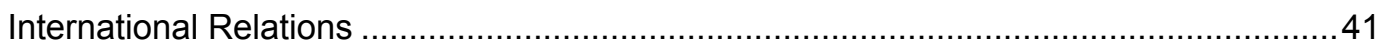

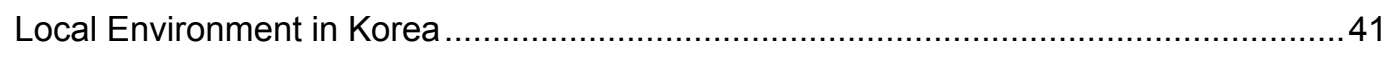

JP-8 Fuel for Space/DHW Heating ................................................................. 42 


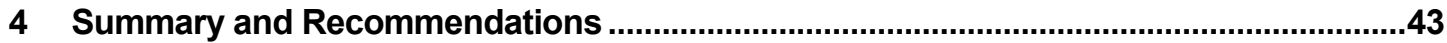

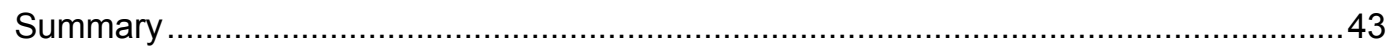

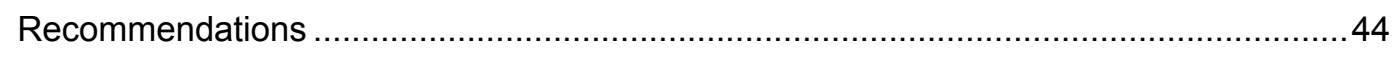

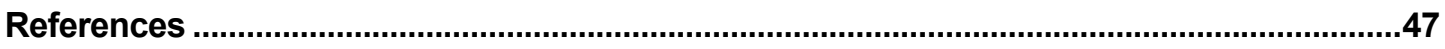

Appendix A: SDD Policy Memorandum (18 Mar 02) from ASA(I\&E) to MACOM

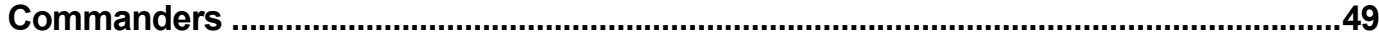

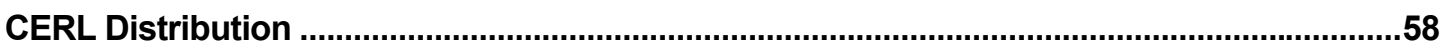

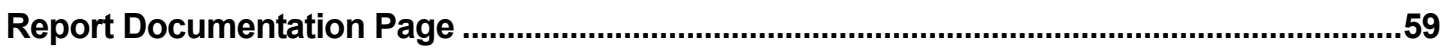




\section{List of Figures and Tables}

\section{Figures}

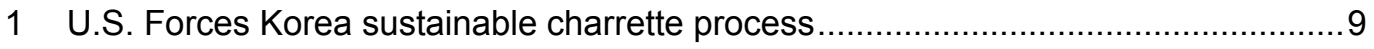

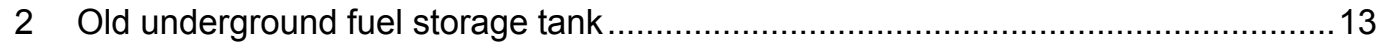

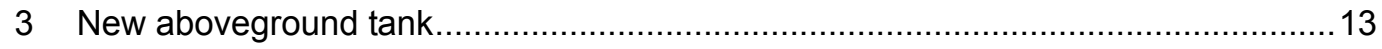

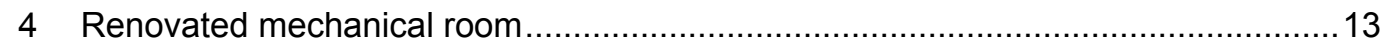

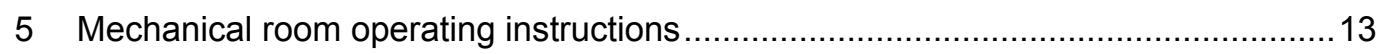

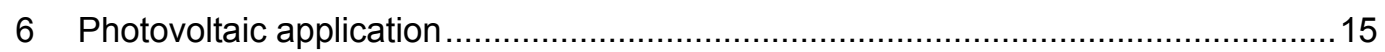

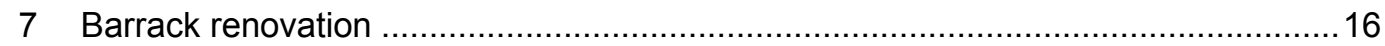

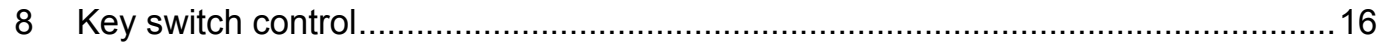

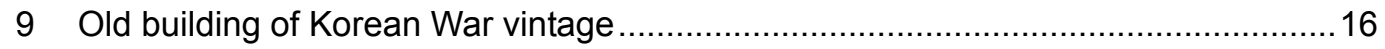

\section{Tables}

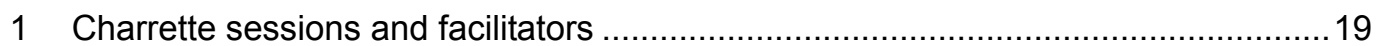

2 EUSA FYO0 energy consumption and cost ......................................................... 


\section{Introduction}

\section{Background}

Engineer Technical Letter (ETL) 1110-3-491* requires U.S. Army Corps of Engineers (USACE) Districts to begin incorporating sustainable design and development (SDD) principles into their projects. (Appendix A to this report contains the SDD policy memorandum from the Assistant Secretary of the Army, Installations and Environment [ASA(I\&E)] to Major Army Command [MACOM] Commanders.) U.S. Army Engineer Research and Development Center, Construction Engineering Research Laboratory (ERDC/CERL) developed the Sustainable Project Rating Tool (SPiRiT) ${ }^{* *}$ to help USACE Districts self-evaluate the sustainability of their facility construction and repair projects. To meet the requirements for sustainable design, the USACE Far East District (FED) has begun SDD training for its engineers and customers with the Eighth U.S. Army (EUSA) installations in Korea. As a part of this training, FED conducted a SDD charrette 26-28 February 2002. Researchers from ERDC/CERL and the Parsons Company (a contractor for FED) assisted as topic presenters and as facilitators in conducting the charrette during breakout group discussion sessions.

\section{Objectives}

The objectives of this work were to:

1. Conduct and document the proceedings of an SDD charrette at the USACE FED, Seoul, Korea, 26-28 February 2002

2. Discuss and define FED/EUSA-unique issues in the early 2002

\footnotetext{
* Engineer Technical Letter (ETL) 1110-3-491, Engineering and Design—Sustainable Design for Military Facilities (Headquarters, U.S. Army Corps of Engineers [HQUSACE], Washington, DC, 01 May 2001).

${ }^{* *}$ SPiRiT (available through the Internet at URL http://www.cecer.army.mil/SustDesign/SPiRiT.cfm) is based on LEED $2.0^{\mathrm{TM}}$, Copyright $\odot 2000$ by U.S. Green Building Council.
} 
3. Provide input to the EUSA installation design guide currently under development by FED

4. Compile a "snapshot" of issues facing EUSA installations in Korea in early 2002.

\section{Approach}

1. ERDC/CERL researchers made preliminary site visits to two representative EUSA installations (to Camp Casey 21 February 2002, and to Yongsan Post 22 February 2002) to familiarize themselves with local characteristics before the SDD charrette. (Observations from these visits are summarized in Chapter 2.)

2. To give charrette participants a clear understanding of what a sustainable future would look like, CERL and Parsons presented briefings defining sustainable design and development concepts relevant to Army installations. Also, long-term sustainability goals established for Continental United State (CONUS) Forces Command (FORSCOM) installations were shown to the audience. These initial briefings helped participants understand the vision of how long term sustainability goals for Korean U.S. Army facilities could reduce their environmental impact and create more secure and sustainable places to work and live." Figure 1 shows the overall U.S. Forces Korea Sustainable Charrette Process. The process simply breaks down to: Baseline, Vision, Goal-Setting, and Commitment. A similar charrette process can be used to define SPiRiT goals for an individual design project, or to establish 1391project requirements. **

3. FED coordinated logistics of the charrette and preparation of the topic material. ERDC/CERL staff and Parsons consultants served as topic presenters and breakout group session facilitators. SDD charrette participants (over 40 EUSA and FED engineers, architects, planners, and contractors from throughout the Korean Peninsula, identified current issues facing the EUSA installations in Korea. Chapter 2 ( p 17) includes the charrette agenda.

\footnotetext{
* More information on the FORSCOM Installation Sustainability Program can be found at URL: http://www.envquest.com/home.asp

${ }^{* *}$ Two Engineering and Construction Bulletins (ECBs) on this topic are accessible through URL: http://www.cecer.army.mil/SustDesign/Charrette.cfm
} 


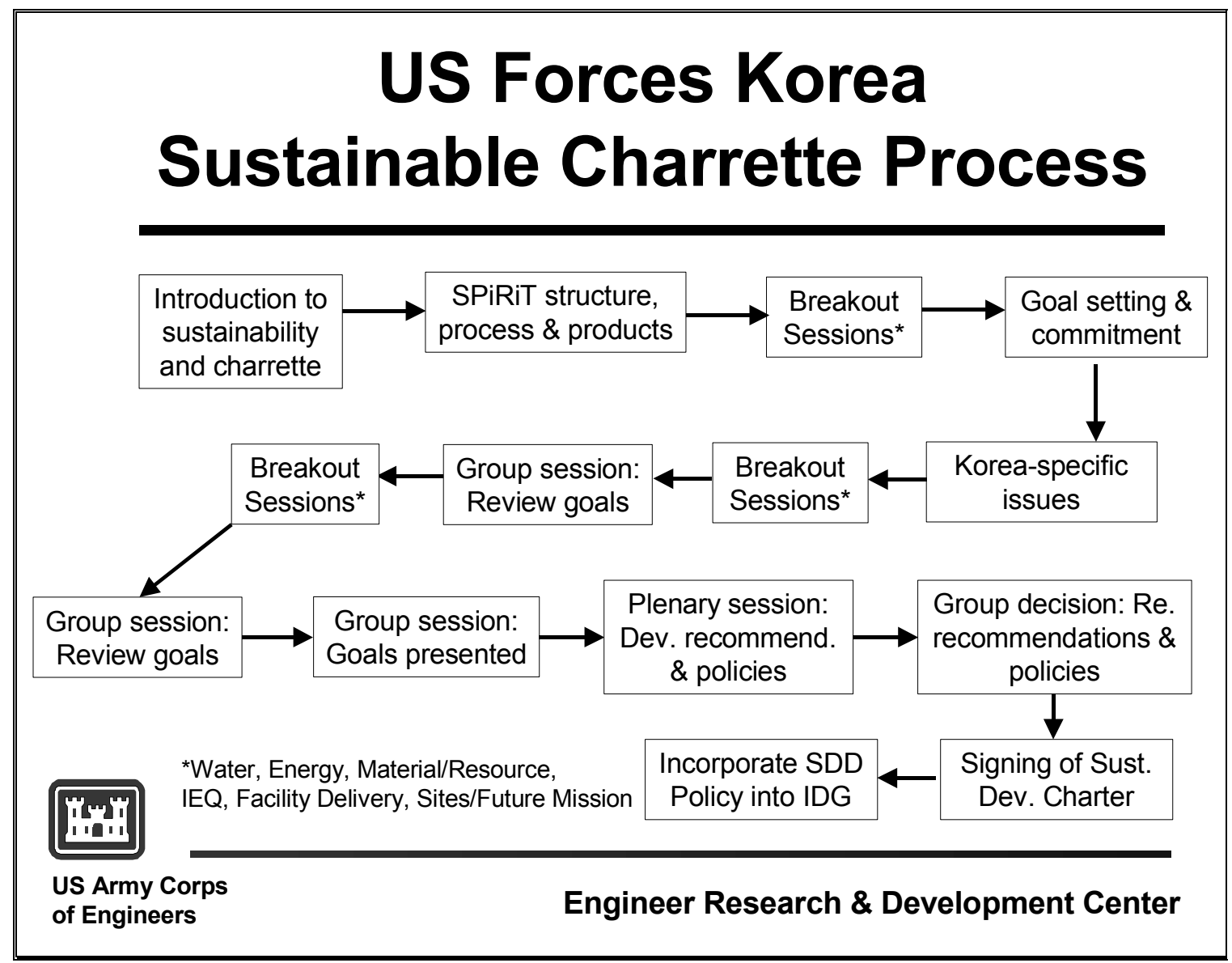

Figure 1. U.S. Forces Korea sustainable charrette process.

4. Charrette participants identified six categories of SDD goals:
a. water
b. energy
c. material/resources
d. indoor environmental quality
e. facility delivery
f. sites/future missions.

5. Issues (including a number of unique issues facing FED in Korea) and goals were identified and developed in each category.

6. At the conclusion of the charrette, participants developed mission and policy recommendations, and an SDD "vision statement."

\section{Scope}

This work documents the SDD charrette at FED in February 2002, including group discussions and recommendations made as part of the charrette proceed- 
ings. Project implementation and program development of the SDD goals are beyond the scope of this work.

\section{Mode of Technology Transfer}

It is anticipated that the identified SDD goals and recommendations will be incorporated into the EUSA installation design guide currently under development. Data in this report will also be useful for the engineers at EUSA installations in project development and future project performance measurement. 


\section{Sustainable Design and Development Charrette at FED}

\section{Preliminary Site Visit}

\section{Camp Casey}

ERDC/CERL researchers made a site visit to Camp Casey 21 February 2002. Assistance from Directorate of Public Works (DPW) staff was considered critical in understanding local conditions. Researchers visited several barracks complexes (both old and new), office buildings, and a dining facility, and then took a driving tour of the camp in general. The following sections list field observations made during the site visit.*

\section{Installation Transportation Network}

- Public transportation (buses) provided because soldiers are not allowed to bring personal vehicles on post.

- Inadequate parking for privately owned vehicles due to space restrictions.

- Less cars reduce potential security risks at checkpoints.

- Bicycles are commonly used.

- Nice covered bike parking areas near all barracks.

- Bus stop shelters.

- Safe pedestrian areas.

- Can be considered a good example for CONUS installations.

\section{Heating}

- JP-8 fuel is used for diesel burner without conversion.

- Pollution control is done by visual adjustment of flame color.

- Parts are from the United States.

- Facility is staffed by on-post Korean technicians.

\footnotetext{
${ }^{*}$ Note that comments have been recorded as written. Stylistic editorial changes are set off in square brackets [ ].
} 
- A small district heating was in operation, but has been phased out due to line failure and repair cost.

\section{Cooling}

- Air cooled central air-conditioners (A/C) are being installed in individual buildings.

- Many old buildings still have window A/C units.

- Heating and cooling are on two-pipe systems.

- No building cooling was installed before 10-15 yr ago.

- There are no ground source heat pumps (GSHP) on post.

- Heat pump (air-to-air) is not commonly used at Camp Casey (about 10 units for officers' family housing units).

- Dining facility currently has $\mathrm{A} / \mathrm{C}$ trouble.

\section{Distributed Energy Generation}

Distributed generation is not known. (Critical buildings, e.g., medical, communication, have their own JP-8 standby generators.)

\section{Barracks}

Two barracks (one old and the other new one) were studied further in detail:

- Old Barrack: 14-yr old, no ventilation, hot water heating only (fan coil), underground fuel storage tank (leakage problem) (Figure 2).

- New Barrack: Less than 1-yr old, ventilation fan/duct, hot water space heating (fan coil), above ground fuel tank (Figure 3), two-pipe system for heating and cooling, air-cooled 50-ton chiller, renovated mechanical room (Figure 4), and good maintenance practice of posting operating instructions on the wall (Figure 5).

\section{Administration Buildings}

- $\quad$ Old-10-yr old, heating only, and no DHW/No ventilation.

- New-6-month old, DHW, AH for Heating/Cooling with duct, two-pipe system, and above ground fuel tank.

\section{Dining Hall}

- Air-cooled AC with AH, JP-8 boiler, and above ground fuel tank.

- Note from technicians: Air Handler above ceiling has little room to service the units. Need more space or on-the-floor installation. Relay the message to designers for more space in above-ceiling installation. 


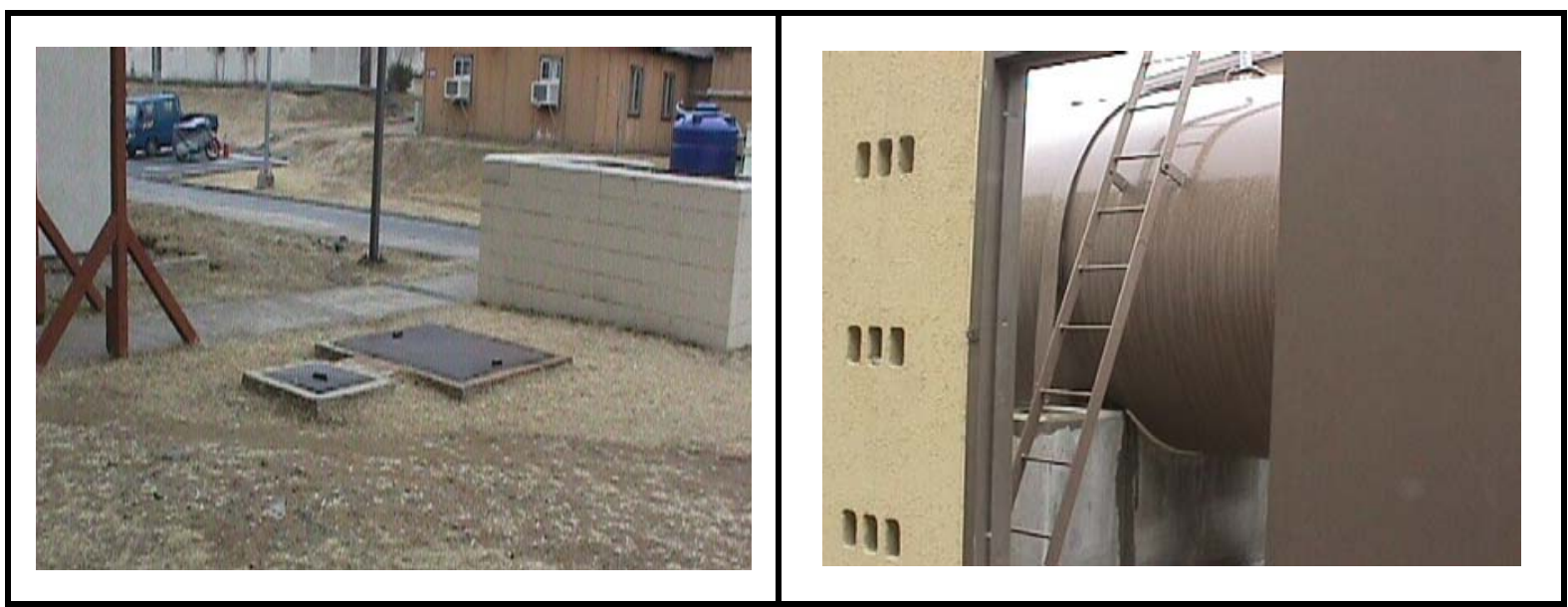

Figure 2. Old underground fuel storage tank.

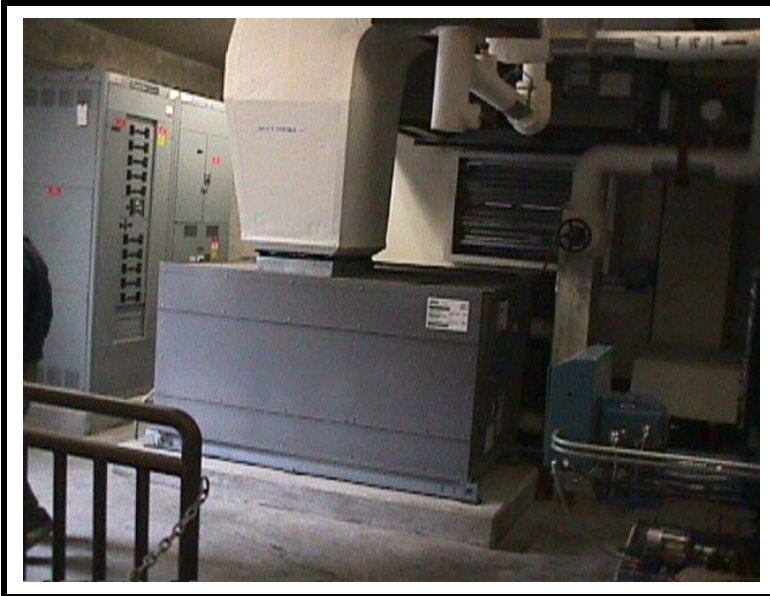

Figure 3. New aboveground tank.

Figure 4. Renovated mechanical room.

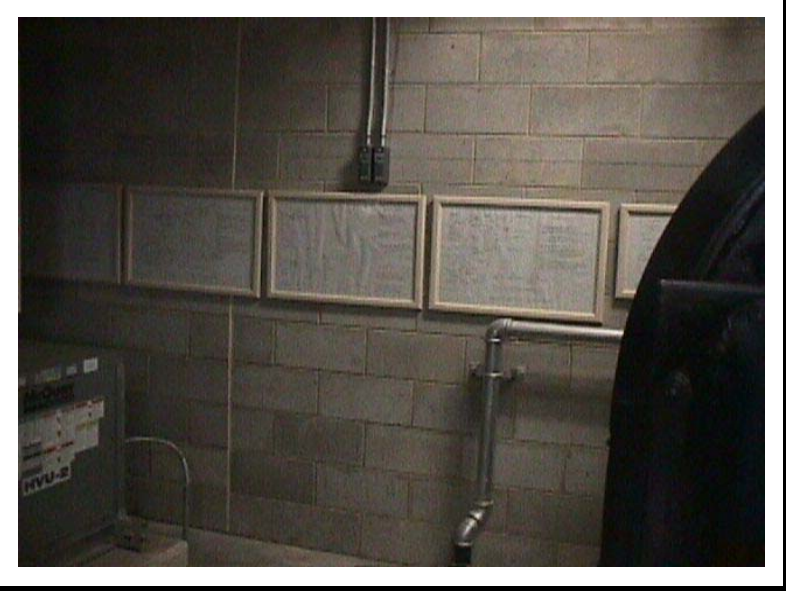

Figure 5. Mechanical room operating instructions.

\section{Yongsan Post}

A site visit to Yongsan Post was made on 22 February 2002. The interview with Mr. Dan Greene, Acting DPW, was considered critical in understanding local conditions. The following sections list issues drawn from the discussion with $\mathrm{Mr}$. Greene and from a walking tour of the post.

\section{Observations Drawn from Interview}

\section{Fuel (Natural Gas vs. JP-8 Oil)}

- Generator has problem with JP-8 fuel (instead of typical diesel fuel).

- Manufacturer's warranty is in jeopardy.

- $\quad$ Space heating with JP-8 oil.

- Has been used in the Eighth U.S. Army (EUSA) less than 5 yr.

- Natural gas is more expensive than JP-8. (Natural gas is purchased at the local market rate, while JP-8 is purchased at the DOL rate.)

- A $\$ 3 \mathrm{M}$ gas line contract was just awarded for the South Post. 
- Even with gas heating, JP-8 can be used for emergency fuel (with dual fuel burner, generator).

- Natural gas is preferred to JP-8. (EUSA tried to avert the JP-8 decision for many years.)

\section{Ground Source Heat Pump (GSHP)}

- Implementation through ESPC is preferred, due to lack of funds.

- ESPC contract process is not smooth.

- GSHP is being demonstrated at the embassy suite (EUSA funding) by the TRANE Company with its local subcontractor.

- Dan has GSHP in his duplex (6-ton unit at $\$ 48 \mathrm{~K})$.

- Since natural gas is not available yet, GSHP is preferred to JP-8.

- Concerns of GSHP in relocation/discontinuation of building use (ground loop cannot be moved).

- In his unit, methanol was needed for freeze protection (to $25^{\circ} \mathrm{F}$ ).

- Issues in retrofit application-excessive duct pressure (due to low delta $\mathrm{T}$, thus higher volumetric air flow rate), noise, relatively low delivery air temp (compared to the accustomed gas heating in CONUS).

- No M\&V yet. Started in September/October 2001.

- Staffing issue-typical (no excessive concern at this stage).

\section{Cooling/Air Conditioning}

- Most of buildings still have window units.

- Conversion to air-cooled chillers is on-going.

\section{International political issues}

- Yongsan Post is in the middle of the crowded City of Seoul.

- There is constant rumor/pressure of facility relocation.

- Golf course has been turned over to the host nation.

- Coordination with the host nation local Government is needed. (An example of this need for coordination is the design change of number of floors and relocation of a high-rise housing unit from 8 to 5 during bidding stage not specified by the customer, but made to satisfy local government requirements.)

- Electricity is provided at the privileged rate, but the natural gas cost will be at the local market rate.

\section{Observations from a walking tour of Yongsan Post:}

- JP-8 oil tanks appear to be old.

- New UL-rated local JP-8 oil tanks are being employed.

- Underground fuel delivery pipe condition was difficult to examine. 
- Application of PV photovoltaic technology for emergency power backup (Figure 6).

- Most of the buildings have window units for cooling.

- Renovations (Figures 7 and 8) are on going, including air-cooled chillers/JP-8 boilers with fan coils and ventilation air in individual rooms. This appears to be the most logical choice, even at higher energy consumption rates (benefits include simplicity in control, individual room occupant control, and low maintenance requirements.

- A few Korean-War era buildings were noticed. Two Quonsets were connected to make a large working space in Figure 9.

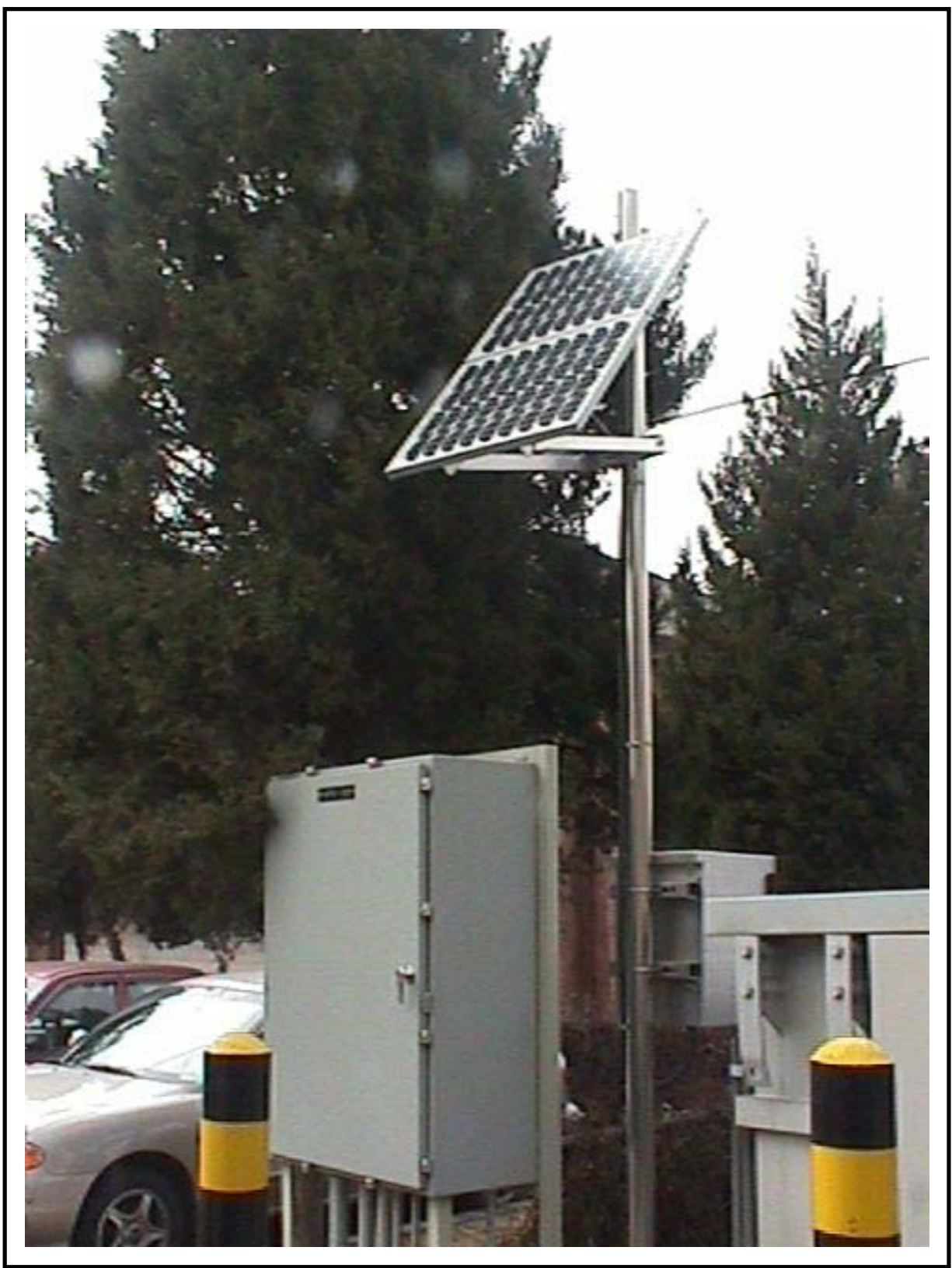

Figure 6. Photovoltaic application. 


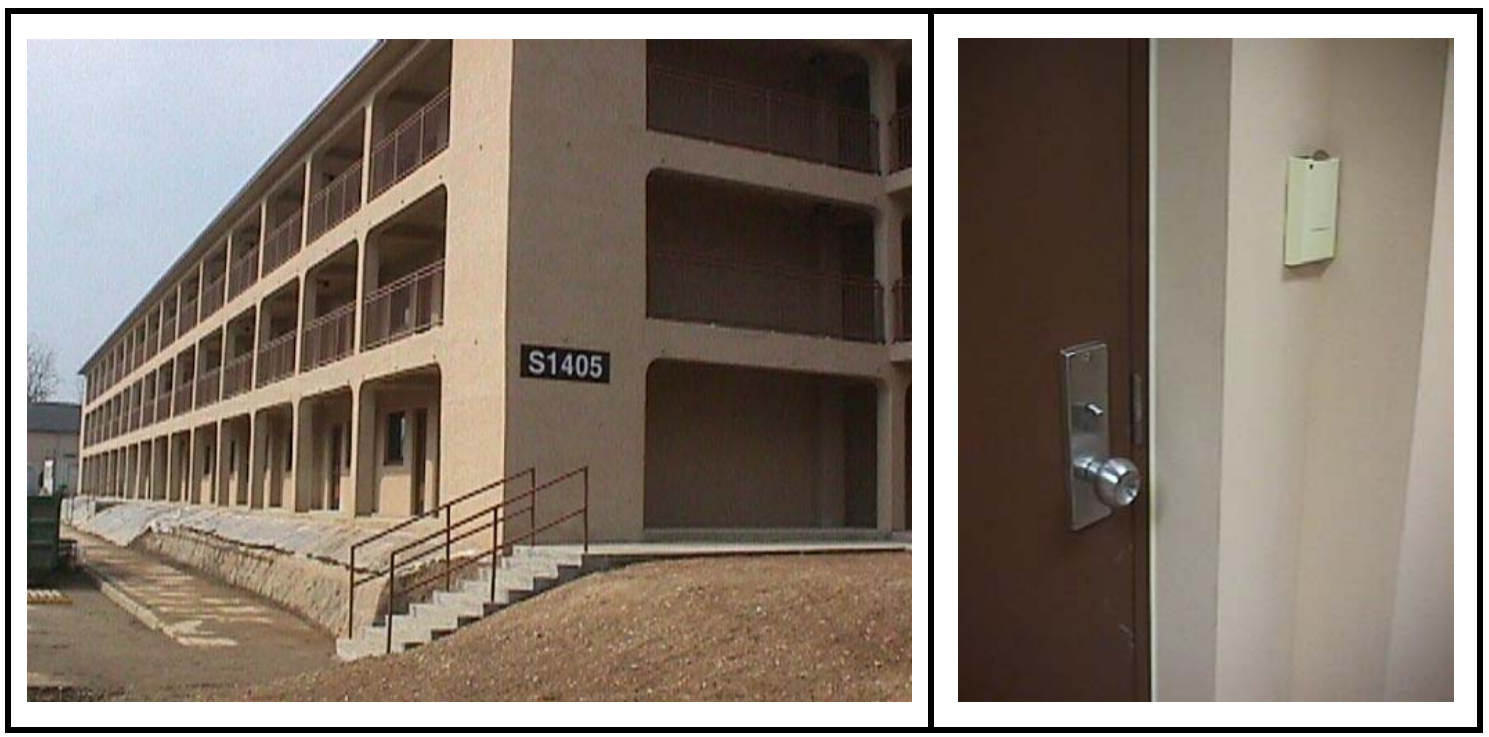

Figure 7. Barrack renovation.

Figure 8. Key switch control.

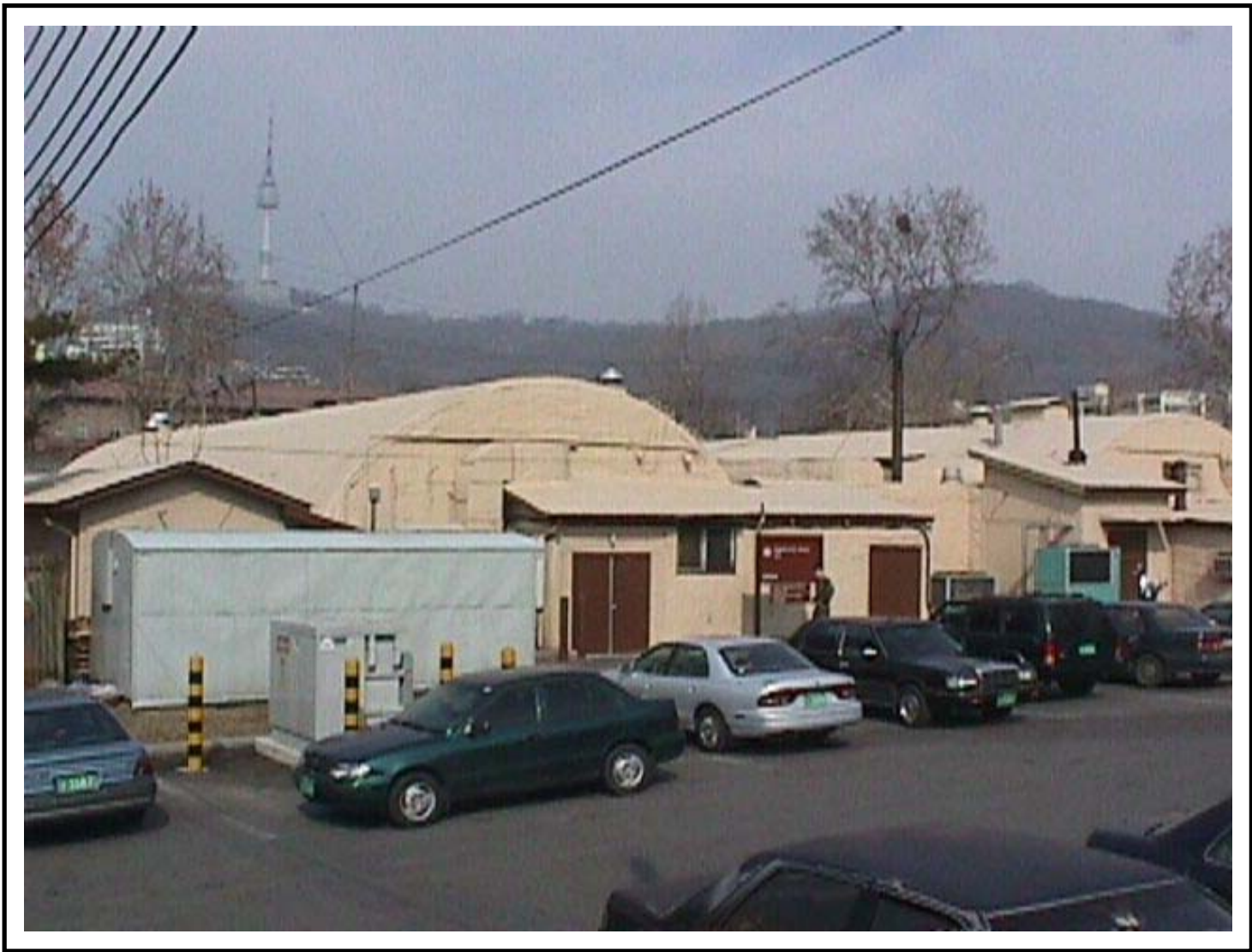

Figure 9. Old building of Korean War vintage. 


\title{
Charrette Agenda
}

\section{Agenda}

\section{Sustainability Charrette-Korea \\ 3-day agenda}

(Plenary; immersion; breakout; development of recommendations and policy).

Charrette Staff:

ERDC-CERL Annette Stumpf, Research Architect

Chang Sohn, Mechanical Engineer

Roch Ducey, Electrical Engineer

Parsons Chris Basham, Architect

Rob Smith, Project Manager

Day 1 (26 February 2002, Tue) - BASELINING

\begin{abstract}
0800-0820: Opening Speech [COL. Kuhr, FED Commander]
0820-0830: Charrette Staff Introduction [Opening Speaker]

0830-0930: Introduction to Sustainability and Charrette [Basham/Stumpf]

0930-1000: Charrette Goals [Basham/Stumpf]

1000-1015: Morning Break

1015-1100: $\quad$ Topic 1-SPiRiT-History and Structure [Stumpf]

11:00-1200: $\quad$ Topic 2-SPiRiT—Process and Products [Stumpf]

1200-1300: $\quad$ Lunch Break

1300-1345: Energy Technologies Overview [Ducey/Sohn]

1345-1400: Guide to Breakout Session [Basham/Stumpf]

1400-1515: Breakout Group Session 1-Water [Stumpf/Smith], Energy [Ducey/Sohn], and Materials/Resources Info [Basham]

1515-1530: $\quad$ Afternoon Break

1530-1645: Breakout Group Session 2 -IEQ [Sohn], Facility Delivery [Stumpf/Ducey], and Sites/Future Missions Baselining [Smith/Basham]

1645-1715: $\quad$ Summary of Day 1, and Heads up for Tomorrow [Basham]
\end{abstract}

Day 2 (27 February 2002, Wed)_GOAL SETTING

0800-0900: Topic 3-Goal Setting and Commitment Processes—Vectors [Basham]

0900-1000: $\quad$ Topic 4-Korea Specific Issues [All/Basham]

1000-1015: Morning Break

1015-1100: Breakout Group Session 3-Water [Stumpf/Smith], Energy [Ducey/Sohn], and Material Resource Draft Goals [Basham]

11:00-1200: $\quad$ Group Session—Goals Review [All] 


\begin{tabular}{|c|c|}
\hline 1200-1300: & Lunch Break \\
\hline 1300-1330: & Recap of Morning Session, and Guide to Breakout Session [Basham] \\
\hline 1330-1500: & $\begin{array}{l}\text { Breakout Group Session 4-IEQ [Sohn], Facility Delivery [Stumpf/Ducey], and } \\
\text { Sites/Future Mission Goals [Smith/Basham] }\end{array}$ \\
\hline 1500-1515: & Afternoon Break \\
\hline 1515-1630: & Group Session—Goals Review [All] \\
\hline 1630-1700: & Summary of Day 2, and Heads up for Tomorrow [Basham] \\
\hline & Day 3 (28 February 2002, Thu) - VISION AND COMMITMENT \\
\hline 0800-0830: & Recap of last 2 days [Basham/Stumpf] \\
\hline 0830-0915: & Sustainable Site Goals [Basham/Stumpf] \\
\hline 0915-1000: & Water and Energy Goals [Stumpf/Sohn/Ducey] \\
\hline 1000-1015: & Morning Break \\
\hline 1015-1100: & Material and Resource and Indoor Environmental Quality Goals [Basham/Smith] \\
\hline 11:00-1200: & Facility Delivery and Mission Goals [Basham/Smith] \\
\hline 1200-1300: & Lunch Break \\
\hline 1330-1500: & Plenary Session for Development of Recommendation/Policy [All] \\
\hline 1500-1515: & Afternoon Break \\
\hline 1515-1630: & Group Decision on Recommendation and Policy (Written Product) [All] \\
\hline 1630-1700: & Signing of Sustainable Development Charter and Conclusion \\
\hline
\end{tabular}

\section{Attendees}

Charrette session attendees were field engineers from the Corps of Engineers Far East Division (CEPOF) and the Eighth U.S. Army (EUSA).

\section{Data Generation}

\section{Description of Six Breakout Sessions}

The charrette participants were divided into six groups: (1) water, (2) energy, (3) materials/resources, (4) indoor environmental quality (IEQ), (5) facility delivery, and (6) sites/future missions. (Table 1 lists the six breakout sessions by topic, and the associated facilitators.) These groups stayed the same through the 3-day charrette. Each group developed baseline data during the first day, prioritized lists during the second day, and formulated goals during the third day. The following sections list results from these sessions. 
Table 1. Charrette sessions and facilitators.

\begin{tabular}{|l|l|}
\hline Session & Facilitator \\
\hline 1. Water & Stumpf/Smith \\
\hline 2. Energy & Ducey/Sohn \\
\hline 3. Materials/resources & Basham \\
\hline 4. Indoor environmental (IEQ) & Sohn \\
\hline 5. Facility delivery & Stumpf/Ducey \\
\hline 6. Sites/future missions & Smith/Basham \\
\hline
\end{tabular}

\section{Baseline Data}

Raw data generated during the first-day baselining sessions are listed in the following. Note that these lists were neither refined nor prioritized. Refinement by all the participants was made the second day; the results are shown in the next chapter.

\section{Water Issues}

- Runoff-down stream flooding, clay ground, steep slopes.

- Flooding on installations.

- Potable water used for everything = waste.

- No current reuse of water.

- Quality of water discharge is poor.

- Building in floodplains.

- Water shortage during drought.

- Poor recharge of groundwater.

- Groundwater contamination.

- Poor water conservation programs.

- Distribution system is old (service laterals) - leaks and rust (hard water, $\mathrm{pH})$.

- Septic tanks in area that flood.

- No irrigation.

\section{Energy Issues}

- Poor energy program-no global vision.

- No planning guidelines-limited availability.

- Limited application of typical energy conservation measures and even less support for innovative methods.

- No structuring for accountability or results (limited metering, limited monitoring, no program management, no responsible parties).

- Funding shortfalls. 
- Need for immediate flexibility for heating vs. cooling needs yet mechanical systems do not support (four-pipe vs. two-pipe heating/cooling distribution systems).

- JP-8 fuel source has environmental impact—emissions, spills, groundwater-natural gas is a better choice. JP-8 is used universally by military for mobile forces. JP-8 is subsidized thus skewing economic analysis/costs.

- Poor response repairs on all current natural gas systems on installations.

- "Fenced" energy funds are redirected.

- Alternative fuels are not fully explored/supported.

- Electric use and prices are rising.

- Cooling loads are dramatically increasing.

\section{Material /Resource Issues}

- Recycling at installations is limited and incomplete systems with local economy.

- Command theme of building taller will lead to changes in material choices.

- Need to re-examine relevance and requirement for U.S. specs versus local materials.

- LPP local product procurement is an opportunity for more sustainable development.

- U.S. products not easily repaired with Korean products.

- Buy Korean first on a cost basis unless there is a safety issue. For example, in Korea asbestos can be found in some products such as ceiling tiles.

\section{Indoor Environmental Quality Issues}

- Poor air circulation in buildings-infiltration vs. forced ventilation.

- Old buildings with no ventilation standards.

- Numerous substandard conversions of reused facilities with change of occupancy types.

- Lack of awareness with VOC volatile organic compounds and IAQcultural acceptance of existing conditions.

- Lack of adequate manpower for proper filter maintenance (outdoor air quality impacts).

- Smoking areas not enforced (i.e., regulations specify that smoking areas be located $50 \mathrm{ft}$ from buildings).

- Lack of duct maintenance.

- Lack of exhaust fans in proper areas (copy rooms, bathrooms, kitchens, mechanical rooms, etc.). 
- Not meeting fresh air requirements.

- No inside humidity controls-dry in winter.

- Mildew problems.

- IAQ is a force protection concern.

- Local inability to measure and monitor indoor environmental quality.

- IAQ not included in commissioning process.

\section{Facility Delivery Process Issues}

- Design team does not consider wider site and area issues.

- Project delivery team is not part of project programming and too short of time for process.

- 1391 does not fully define scope of work.

- $\quad$ Need $\$ \$$ and 1391 to include and address sustainable design and development.

- Need procedures for team to track and update 1391 until approved.

- Training gap for O\&M Operations and Maintenance commissioning and maintenance folks.

- Need better communication between designers, O\&M, and users to understand choices and consequences.

- Need to add contractor provided training to O\&M into specs (or contractor to maintain).

- Korean products first cost basis unless safety issue.

- Need extra materials to repair new buildings.

- In Korea asbestos can be found in some products such as ceiling tiles.

- Low bid does not support SDD vs. best value.

- Language barriers with O\&M manuals-host nation projects in two languages, the United States projects in one language-consider digital availability of manuals.

- Need champions and processes to better support SDD innovations.

- Collaborative design process requires more communication and time.

- Final inspection and acceptance team should include project delivery team as a common practice.

- 25-yr vision requires specific and focused commitments.

\section{Sites and Future Mission Issues}

- Inherited old buildings and old problems.

- LPP is opportunity for SDD.

- Poor circulation infrastructure for peds and pedals pedestrians and bicyclists.

- Sustainability versus Anti-Terrorism/Force Protection (ATFP).

- Asphalt considered hazardous in Korea.

- Tree maintenance/preservation. 
- North of Seoul and distance from cities considered undesirable.

- Fort Future.

- No installations in Korea.

- Joint with ROK.

- If reunification-mission changes.

- Need guidance for planning and design of high-rises.

- Military designs not in accord with local designs.

\section{Group Prioritized List}

During the second-day plenary session, all the participants reviewed the firstday raw data. The baseline raw data were clarified and consolidated if applicable. Each participant was given 10 points to vote. The group prioritized the issues as following. Numbers shown are the number of points given by the charrette participants.

\section{Water Issues}

11 - Groundwater contamination.

7 - No current reuse of water.

$5-$ Potable water used for everything = waste.

4 - Distribution system is old (service laterals) - leaks and rust (hard water, ph).

3 - Poor water conservation programs.

3 - Water shortage during drought.

- Runoff_-downstream flooding, clay ground, steep slopes.

- Flooding on installations.

- Quality of water discharge is poor.

- Building in floodplains.

- Poor recharge of groundwater.

- Septic tanks in area that flood.

- No irrigation.

\section{Energy Issues}

15 - JP-8 fuel source has environmental impact-emissions, spills, groundwater. Natural gas is a better choice. JP-8 used universally by military for mobile forces. JP-8 is subsidized thus skewing economic analysis/costs.

$8-$ Limited application of typical energy conservation measures and even less support for innovative methods.

$8-$ Alternative fuels not fully explored/supported.

$6-$ Funding shortfalls.

5 - No planning guidelines-limited availability. 
- No structuring for accountability or results (Limited metering, limited monitoring, no program management, no responsible parties).

- Need for immediate flexibility for heating vs. cooling needs yet mechanical systems do not support (four-pipe vs. two-pipe heating/cooling distribution systems).

- Poor energy program-no global vision.

- Poor response repairs on all current natural gas systems on installations.

- $\quad$ "Fenced" energy funds are redirected.

- Electric use and prices are rising.

- Cooling loads are dramatically increasing.

\section{Material /Resource Issues}

14 - Buy Korean first on a cost basis unless there is a safety issue. For example, in Korea, asbestos can be found in some products such as ceiling tiles.

3 - Command theme of "going vertical" will lead to changes in material choices.

- Need to re-examine relevance and requirement for U.S. specs versus local materials.

- LPP is opportunity for more sustainable development.

- U.S. products not easily repaired with Korean products.

- Recycling at installations is limited and incomplete systems with local economy.

\section{Indoor Environmental Quality Issues}

9 - Poor air circulation in buildings-infiltration vs. forced ventilation.

9 - No inside humidity controls-dry in winter.

6 - Duct maintenance.

5 - Lack of adequate manpower for proper filter maintenance (Outdoor air quality impacts).

5 - Numerous substandard conversions of reused facilities with change of occupancy types.

- Lack of awareness with VOC and IAQ - cultural acceptance of existing conditions.

- Smoking areas not enforced (i.e., regulations specify that smoking areas be located] $50 \mathrm{ft}$ from buildings).

- Lack of exhaust fans in proper areas (copy rooms, bathrooms, kitchens, mech rooms, etc.).

- Not meeting fresh air requirements.

- $\quad$ Old buildings with no ventilation standards. 
- Mildew problems.

- IAQ is a force protection concern.

- Local inability to measure and monitor indoor environmental quality.

- IEQ not included in commissioning process.

\section{Facility Delivery Process Issues}

13 - No project delivery team. Project delivery team not part of project programming and too short of time for process. Design team does not consider wider site and area issues.

12 - Low bid does not support SDD vs. best value.

9 - Final inspection and acceptance team should include project delivery team as a common practice.

7 - Need better communication between designers, O\&M, and users to understand choices and consequences.

4 - 25-yr vision requires specific and focused commitments.

3 - Collaborative design process requires more communication and time.

- 1391 does not fully define scope of work.

- $\quad$ Need $\$ \$$ and 1391 to include and address sustainable design and development.

- $\quad$ Need procedures for team to track and update 1391 until approved.

- $\quad$ Training gap for O\&M commissioning and maintenance folks.

- Need to add contractor provided training to O\&M into specs (or contractor to maintain).

- Korean products first cost basis unless safety issue.

- Need extra materials for repair for new buildings.

- Korea still uses asbestos in some products, e.g., ceiling tiles.

- Language barriers with O\&M manuals — host nation projects in two languages, the United States projects in one language consider digital availability of manuals.

- Need champions and processes to better support SDD innovations.

\section{F. Sites and Future Mission Issues}

12 - Inherited old buildings and old problems.

8 - Sustainability versus Force Protection/Anti-Terrorism.

6 - Military designs not in accord with local designs.

2 - LPP is opportunity for SDD.

- Poor circulation infrastructure for peds and pedals (pedestrians and bicycles).

- Asphalt considered hazardous in Korea. 
- Tree maintenance/preservation.

- North of Seoul and distance form cities considered undesirable.

- Fort Future.

- No installations in Korea.

- Joint with ROK.

- If reunification-mission changes.

- Need guidance for planning and design of high-rises.

\section{Goal and Vision Development}

On the third day, each group identified the most salient issues in each category. They also identified the desired end state for each of the issues, developed the time frame and established metrics to gauge the progress toward the end states. Results of these activities are listed in the following.

\section{Water Issues}

\section{Water Issue 1-Description}

Water Conservation Programs either do not exist or are not maintained. Water conservation practices are necessary to assure that future water requirements can be met.

\section{Water Issue 1-Responses}

- Water sources wells, rivers, city water.

- Sources are becoming more stressed as populations/development increase.

- Ground water is becoming more polluted decreasing sources.

- Water is not recycled/reused.

- Potable water used for all water uses.

- Water shortages are experienced during droughts.

\section{Water Issue 1-Desired End State}

- Plan and implement a sustainable water conservation program.

- Plan and implement a water recycle/reuse program.

- Educate population on the need/methods to conserve water.

- Use central wash racks that use non-potable/recycled water/remove wash racks from maintenance areas.

- Use water efficient fixtures. 


\section{Water Issue 1-Timeframe}

Replace all existing plumbing in $12 \mathrm{yr}$.

\section{Water Issue 1-First Two Steps}

1. Provide water filters to potable water faucets

2. Need to have on going pipe replacement program to replace with best available product, e.g., PVC, CPVC (which are less corrosive materials).

Other suggestions included:

- Change the water PH chemical additives.

- Convince/persuade HQs that facilities need to be replaced every $12 \mathrm{yr}$ rather than $25 \mathrm{yr}$.

\section{Water Issue 2-Description}

We use potable water for all purposes.

Water Issue 2-Responses

- Identify the big water users and recommend a plan to use gray water for future projects.

- Design new buildings with gray water systems in mind.

\section{Water Issue 2-Desired End State}

- Separate uses of water.

- Use potable water for drinking and washing people and food.

- Use gray water for equipment washing, landscaping (and toilets?).

- Consider gray water: raw water, well water, rain water, and treated sewage.

- Institute a water conservation program.

\section{Water Issue 2-Metric}

- Measure quantity of potable water used before and after gray water projects are developed. Show amount of potable water saved per capita.

- 20 percent reduction in potable water used.

\section{Water Issue 2-Timeframe}

1 yr. Identify big water users and prepare plan to renovate. 


\section{Water Issue 2-First Two Steps}

1. Convert potable water use to gray water for landscaping, equipment washing. Consider cisterns.

2. Consider double piping systems for toilets.

Other suggestions included:

- Identify and persuade big potable water users to convert to gray water. Plan projects and renovate.

- Budget for centralized wash racks.

- Install water meters for potable water.

- Meter usage of potable water.

- Install oil/water separators for centralized wash facilities.

\section{Water Issue 3-Description}

Water quality is generally good but is degraded by poor quality distribution system that is deteriorated and adds leaks.

\section{Water Issue 3-Responses}

- Water quality in Korea causes rapid deterioration of pipes.

- Pipes are corroded so water pressure is impeded and water quality is degraded.

- Systems leak so water is lost.

- Systems are old and need replacement.

- Most main distribution systems have been replaced. Some installations in process and still to be done.

- Lateral and building pipes need replacement/maintenance.

\section{Water Issue 3-Desired End State}

- Determine life span of systems.

- Plan and implement pipe system replacement/maintenance.

- Program system replacement.

\section{Water Issue 4-Description}

Groundwater is contaminated.

\section{Water Issue 4-Responses}

- USTs have been a major cause of contamination. There is an ongoing program to remove all USTs and replace them with double wall above ground storage tanks. 
- Previously undiscovered USTs from before U.S. Army occupation of land have been found that have leaked for years.

- Fuel spills before cleanup was required.

- Cleanup programs in place for fuel spills often not totally effective.

- Runoff from roadways and maintenance areas.

- Trans Korea pipeline has caused contamination. Abandoned and taken over by ROK who are now removing pipeline.

- Fuel pipelines should be checked for leakage and replaced if necessary.

- Use of fertilizers on and off post add to groundwater contamination.

- Septic systems.

\section{Water Issue 4-Desired End State}

- Ongoing programs to prevent future groundwater contamination and cleanup existing as much as possible.

- Replace fuel oil heating systems with other energy source. Natural gas systems, geothermal, solar panels/passive solar design could be used.

- Provide ongoing leak detection of pipe systems.

\section{Water Issue 4-Metric}

- Install 30 percent of natural gas distribution system for Korea installation by 2010 .

- Convert existing large users to natural gas and build all new facilities to use natural gas.

\section{Water Issue 4-Timeframe}

- 10 percent in $3 \mathrm{yr}$.

- 20 percent by 6 yr.

- 30 percent by 8 yr.

\section{Energy Issues}

\section{Energy Issues-Description}

- Funding shortfalls.

- Alternative fuels not fully explored/supported-JP-8 fuel source has negative environmental impact-emissions, spills, groundwater contamination, etc., jeopardizing air and water quality.

- Limited application of typical energy conservation measures and even less support for innovative methods—no planning guidelines-limited availability. 


\section{Energy Issues-Responses}

- Poor energy program-no global vision.

- No planning guidelines-limited availability.

- Limited application of typical energy conservation measures and even less support for innovative methods.

- No structuring for accountability or results (limited metering, limited monitoring, no program management, no responsible parties).

- Funding shortfalls.

- Need for immediate flexibility for heating vs. cooling needs yet mechanical systems do not support flexibility (e.g., four-pipe vs. two-pipe heating and cooling distribution systems).

- JP-8 fuel source has environmental impact-emissions, spills, groundwater-Natural gas a better choice. JP-8 used universally by military for mobile forces. JP-8 is subsidized thus skewing economic analysis/costs.

- Poor response repairs on all current installation natural gas systems.

- "Fenced" energy funds are redirected.

- Alternative fuels not fully explored/supported.

- Electric use and prices are rising.

- Cooling loads are dramatically increasing.

\section{Energy Goals}

\section{Energy Goal 1 Description}

Plan and implement sustainable energy program-increase and "fence" energy funding.

\section{Energy Goal 1 Metric}

Determine present energy consumption baseline (Btu/sq ft/year) and schedule of "fenced" funding required to implement appropriate energy conservation projects, which will help to meet the requirements of EO 13123.

\section{Energy Goal 1 Timeframe}

EO 13123 requires 35 percent reduction in energy consumption by 2010, from 1985 baseline.

\section{Energy Goal 1 First Two Steps}

1. All lighting upgrades by 2005 .

2. Replace all single-pane windows with double-pane windows by 2008 . 


\section{Energy Goal 1 Desired End State}

None stated.

\section{Energy Goal 2 Description}

Diversify energy supply options for fixed facilities—minimize JP-8 pollution.

\section{Energy Goal 2 Metric}

Reduce number of gallons of JP-8 used for space heating, domestic hot water, and electric power generation.

\section{Energy Goal 2 Timeframe}

Complete studies by 2004 .

Demonstration program completed by 2007.

\section{Energy Goal 2 First Two Steps}

1. Identify alternative sustainable fuel sources and perform economic analysis.

2. Estimate implementation costs of sustainable alternative.

\section{Energy Goal 3 Description}

Implement energy codes applicable to local facilities, based on nationally accepted guidelines.

\section{Energy Goal 3 Metric}

Develop energy codes that reduces Btu/sq ft/year, per EO 13123.

\section{Energy Goal 3 Timeframe}

Code development and adoption by 2005 .

\section{Energy Goal 3 First Two Steps}

1. Modify and adopt accepted various national energy codes, for local conditions.

2. Implement adopted energy codes. 


\section{Materials/Resources Issues}

\section{Material/Resources Issues-Description}

Buying Korea first (based on costs) is preferred, but U.S. specs disallow many Korean products, especially in the mechanical and electrical fields. Technical review for new Korean products is not timely and process not easily accessible. Two different groups review for changes or substitutes for products-FED and CCK.

\section{Material/Resources-Responses}

- Local purchases save time and money.

- Easier maintenance for local products.

- Korean work force better able to deal with and maintain Korean products.

- Better response form local manufacturers.

- Underwriters Laboratories, Inc (UL) requirements seem to be the biggest product acceptability issue. Some Korean products may be as safe but do not have the ability to verify their specifications. Specific example may be AC units.

- Korea uses 220V and United States uses 110V. Local products favor $220 \mathrm{~V}$ products. Conversion of installation to $220 \mathrm{~V}$ would be more energy efficient but would impact soldier quality of life. Installation of both $220 \mathrm{~V}$ and $110 \mathrm{~V}$ would be more expensive for installation.

- It is better politically to specify local Korean products.

- There are local manufacturers that make products that meet U.S. specs for export (OEM). Need to explore "peel off" for U.S. uses in Korea.

- Korean products getting better daily. Older reviews may no longer apply. Need a process to better identify acceptable products and review in a more timely manner.

- Host Nation projects still use U.S. specifications.

- Need to program to more aggressively identify acceptable local products.

\section{Material/Resources-Desired End State}

- Majority (90 percent) of products (based on costs) is to be acquired locally.

- Dedicated office to research and find more locally manufactured, U.S. acceptable products.

- Establish access to locally manufactured OEM products. 


\section{Material/Resources-Metric}

- 90 percent of locally acquired products.

- Time and dollars (won) saved per project/by product.

\section{Material/Resources-Timeframe}

- $\quad$ Office in place by end of 2003.

- Key products listing by 2004.

\section{Indoor Environmental Quality (IEQ) Issues}

\section{IAQ-Issues Description}

- New and retrofit construction designs do not completely reflect IAQ and Anti-terrorism/Force Protection (IAQ/ATFP) standards.

- Operation and maintenance funds are limited.

- Current situation is under-manned and under-trained, resulting in minimal attention to IAQ and ATFP standards.

\section{IAQ-Responses}

- Poor air circulation in buildings-infiltration vs. force ventilation.

- Old buildings with no ventilation standards.

- Numerous substandard conversions of reused facilities with change of occupancy types.

- Lack of awareness with VOC and IAQ - cultural acceptance of existing conditions.

- Lack of adequate manpower for proper filter maintenance (outdoor air quality impacts).

- Smoking areas not enforced (i.e., regulations specify that smoking areas be located $50 \mathrm{ft}$ from buildings).

- Duct maintenance.

- Lack of exhaust fans in proper areas (copy rooms, bathrooms, kitchens, mechanical rooms, etc.).

- Not meeting fresh air requirements.

- No inside humidity controls-dry in winter.

- Mildew problems.

- IAQ is a force protection concern.

- Local inability to measure and monitor indoor environmental quality.

- IEQ not included in commissioning process. 
IAQ-Goals

\section{Goal 1 Description}

New and retrofit buildings meet IAQ/ATFP standards, with respect to local meteorological conditions, and verification that IAQ/ATFP standards are being met is included as part of the building commissioning/re-commissioning process.

\section{Goal 1 Metric}

Percentage floor area in sq ft that meets minimum IAQ/ATFP standards.

\section{Goal 1 Time Frame}

Review, revise, and apply standards and train designers in IAQ/ATFP by 2005.

\section{Goal 1 First Two Steps}

1. Review existing IAQ/ATFP standards and increase awareness of these issues to occupants.

2. Incorporate IAQ/ATFP standards in design, construction and commissioning processes.

\section{Goal 2 Description}

To maintain new/retrofitted heating, ventilation, and air conditioning (HVAC) equipment, so that proper IAQ/ATFP standards continue to be met, including circulation, humidity, and filtration.

\section{Goal 2 Metric}

Percentage floor area in sq ft that meets minimum IAQ/ATFP standards.

\section{Goal 2 Time Frame}

Workforce fully trained by 2004 .

\section{Goal 2 First Two Steps}

1. Secure funding and workforce to perform effective HVAC system maintenance

2. Provide technical manuals and training to workforce for preventive maintenance. 


\section{Facility Delivery Issues}

\section{Facility Delivery Issue 1}

A 25-year vision requires specific and focused commitments (which are communicated to project delivery team members).

\section{Facility Delivery Issue Responses}

- High rotation/turn over results in short-term planning only.

- Commander turn over changes priorities.

- Long-term view needs to be clearly defined and communicated enduring installations vs. divesture.

- Starting implementation of master plan. (Is this Master Plan long range and comprehensive-considering all Installations in Korea?)

- Theatre Master Plan conferences are held quarterly. Participants describe projected projects. (Two times so far.) This needs to be communicated to project delivery team members.

- Sustainable Design and Development policy/goals need to be communicated to people involved in the strategic master planning, and local community/government.

\section{Facility Delivery Desired End State}

- 25-year vision clearly defines intent and financial commitment to provide pleasant, sustainable, and modern/upgraded Army facilities for Army troops, families and civilian workers.

- It is desirable to effectively coordinate with local Korean cities/governmental agencies to ensure cooperation, transparency, trust, and smooth project delivery.

\section{Facility Delivery Metric}

Need vision statement, comprehensive master plan, clear sustainability goals and acquisition strategy for consolidation, relocation, demolition, renovation or new design/construction as appropriate.

\section{Facility Delivery Timeframe}

Command vision communicated to installations, FED, and appropriate agencies starting 1 October 2002. 


\section{Facility Delivery First Two Steps}

1. Command Vision needs to be shared with installations and FED and appropriate agencies.

2. Installation Master Plans need to clarify the command vision. (Prepare Long Range and Short Range plans, and start planning facilities, 1391s, etc.)

\section{Facility Delivery-Issue 2 Description}

Low Bid does not support SDD vs. Best Value.

\section{Facility Delivery-Issue 2 Responses}

- Better craftsmanship available via best value contract.

- More timely delivery of projects, and less chance of default.

- Specialized projects/systems need skilled labor.

- Pre-qualified contractor can be used on project-more reliable.

\section{Facility Delivery-Issue 2 Desired End State}

Most efficient reliable contracting method.

\section{Facility Delivery-Issue 2 Metric}

Customer satisfaction survey. (Standardize Corps and CCK contractor survey (rating contractor performance.)

Facility Delivery-Issue 2 Timeframe

Pilot program by FY03.

\section{Facility Delivery-Issue 2 First Two Steps}

1. Make sure contractors are prequalified so they can be hired using the best value contracting method.

2. CCK needs to consider having prequalified bonded contractors.

\section{Facility Delivery-Issue 3 Description}

- It is difficult for the Master Planner to create a fully scoped 1391 alone, with a short time frame. (This causes problems for the entire life of the project.)

- Approved facility does not satisfy the customer.

- Scope is not completely defined.

- Lack of communication among team members and between project phases.

- Need funding to do 1391 effectively. 


\section{Facility Delivery-Issue 3 Responses}

- Project Delivery Team-varies over the life of the project. Need to keep track of participants during each phase to record accountability.

- 1391 preparation stage: Master Planner, User, Project Manager (if COE -Designer, Cost Estimator), Physical Security, Signal \& IMO, DPW (O\&M for renovation), really define the scope, identify SDD, force protection, aging infrastructure problems, site problems; Master Planner leads, updates, tracks 1391;program sufficient funds for project.

- Design: Master Planner, User, Project Manager, Designer, Cost Estimator, Physical Security, Signal \& IMO, DPW (O\&M for renovation), Contracting Officer, Resident Engineer (acquisition strategy-Low Bid vs. Best Value; incorporate SDD principles and set SPiRiT goals and strategies).

- Construction: Master Planner, User, Project Manager, Designer, Physical Security, Signal \& IMO, DPW (O\&M for renovation), Contracting Officer, Resident Engineer, Contractor (PDT visit construction site and see progress; O\&M should see actual equipment in place before it is covered up).

- Commissioning: Master Planner, User, Project Manager, Designer, Physical Security, Signal, DPW (O\&M for renovation), Contracting Officer, Resident Engineer, Contractor. (Final inspection and acceptance team should include project delivery team as a common practice; need to add contractor provided training to O\&M into specs or have contractor maintain.)

\section{Facility Delivery-Issue 3 Desired End State}

- Need to establish project delivery team early to ensure customer satisfaction when facility construction/renovation is completed, commissioned, and accepted.

- Need to fund and enable project team members to participate in project delivery during entire project life, from initiation/1391 development until completion to ensure continuity, continuous process/product improvement, and customer satisfaction.

\section{Facility Delivery-Issue 3 Metric}

- Achieve a good SPiRiT rating for the project.

- User requested modifications are reduced.

- Construction schedule timelines are met.

- Measure customer satisfaction with end project. Survey customer. 


\section{Facility Delivery-Issue 3 Timeframe}

Start FY03.

\section{Facility Delivery-Issue 3 First Two Steps}

1. Develop the role of the project delivery team for each phase, including funding. (Standardize the procedure; consider design/build projects - then it is really important to have charrette and a well developed 1391/scope).

2. Hold a charrette with the project delivery team to fully develop the 1391.

Another suggestion was to develop a web-based criteria development tool to address concerns of the users/DPW and players who will be using the facility. Building Composer, a CERL product, should help teams assemble project requirements into a $1391 . *$

\section{Sites/Future Missions Issues}

\section{Sites and Future Mission-Issue 1 Description}

Potential for conflicts between Sustainability and ATFP.

\section{Sites and Future Mission-Issue 1 Responses}

- Latest force protection guidance results in no trees or plantings around the fence line/perimeter of an installation.

- New buildings have mandated ATFP requirements, but there may not be room on some Korean bases.

- It was felt that the ATFP efforts would be better focused on entrances and perimeters of installations.

- The sustainable act of going vertical saves materials, reduces footprint, saves energy but concentrates personnel and lends itself to greater vulnerabilities.

- Sustainable landscaping actions want to place more vegetation in closer proximities to buildings and paved areas to reduce solar gains yet ATFP requirements require less or no vegetation in some of these areas.

\footnotetext{
* More information on Building Composer is available via the Internet at URL: http://bc.cecer.army.mil/bcl
} 
- The Land Partnership Plan currently holds to a reduction to only eight installations-the Enduring installations. This consolidation and reduction contributes to sustainability.

- There are several sustainable development directions that actually are mutually supportive of ATFP requirements.

\section{Sites and Future Mission-Issue 1 Desired End State}

Relaxation of nonperimeter force protection guidelines with a more concentrated effort focused at entries, perimeters, and key facilities. This would be tailored for each individual installation.

\section{Sites and Future Mission-Issue 1 Metric}

Dollars spent on ATFP.

\section{Sites and Future Mission-Issue 1 Timeframe}

2004.

\section{Sites and Future Mission-Issue 1 First Two Steps}

1. Fully explore the ATFP alternatives to minimize impact on sustainable development and operational efficiencies. Document the cost of applications of ATFP actions relative to the gain or loss of protection.

2. Prepare and present a formal request to CERL, FED and AEPI for consideration.

\section{Sites and Future Mission - Issue 2 Description}

Inheritance of old buildings with old problems.

\section{Sites and Future Mission - Issue 2 Responses}

- Old buildings have a host of problems such as asbestos. These problems results in increased maintenance and less than standard facilities.

- Old buildings lack environmental controls.

- There are many Quonset huts on the installations in Korea. These are inefficient in use of space, contribute to a poor quality of life, are not vertical in accordance with command themes, and result in ugly, high maintenance facilities. 


\section{Sites and Future Mission - Issue 2 Desired End State}

Relaxation of nonperimeter force protection guidelines with a more concentrated effort focused at entries and perimeters. This would be tailored for each individual installation.

\section{Sites and Future Mission - Issue 2 Metric}

Rid the Army in Korea of all obsolete or aged buildings with an overtly high maintenance and or repair costs.

\section{Sites and Future Mission - Issue 2 Timeframe}

2008 for all Quonsets. Lower the age/sq ft of buildings by 20 percent by 2005 .

\section{Sites and Future Mission - Issue 2 First Two Steps}

1. Use the metrics to highlight and understand age/sq ft and maintenance dollars per square foot. Establish a baseline.

2. Expedite the Demo program. Examine the possibility of replacing Quonset huts through the ECIP program by packaging a number of these facilities by installation. Determine the current energy costs and potential savings with consolidation of functions into a single facility or complex of facilities. 


\section{Discussion}

During site visits to Camp Casey and Yongsan Post, and discussion with participants of the FED SDD Charrette, researchers observed a number of issues which are typical in CONUS USACE Districts and installations, and unique in FED and EUSA installations in Korea. The typical common issues are lack of adequate funding and staffing for installation infrastructure, need for improved communication between the designers and users, and the need for construction quality control including the issue of the lowest first cost vs. SDD best cost, commissioning, and operations and maintenance (O\&M).

\section{FED/EUSA Unique Issues in Korea}

The unique local issues are: project life span of less than 5 yr (e.g., "inherited old buildings and old problems"), international relations (e.g., specifications, local product procurement [LPP], and local politics with the host country), local environmental conditions, e.g., "OAQ (outdoor air quality) worse than IAQ (indoor air quality)," the impetus to "go vertical," and the universal usage of JP-8 oil for space/domestic hot water (DHW) heating in EUSA installations in Korea. These unique issues are further elaborated in the following sections.

\section{Project Life Span}

Most of the EUSA installations were either inherited from the Japanese Army after World War II or established during the Korean War more than half a century ago. Until a few years ago, the project life span for FED projects was less than 5 yr. The legacy of the limited project span is shown by practices such as building in floodplains, exercising poor global vision in energy programs, and maintaining old buildings without air conditioning, DHW, or ventilation. Figure 9 (p 16) shows a typical example of "limited project span," in which two Quonsets were connected to provide required space instead of replacing the old Quonsets with a permanent building for the needed working space.

Recently, the project life for EUSA installations has been extended to $25 \mathrm{yr}$, like the project life for CONUS installations. The renovation of barracks ("one-and- 
one") currently under progress in Yongsan Post provides an encouraging example of the Post's willingness to provide quality living space for the soldiers (cf., Figure 7). Renovation of all the old buildings in EUSA installations with the new project life of $25 \mathrm{yr}$ is strongly recommended to provide improved working conditions for the soldiers, civilians, and their families, as well as to improve energy efficiency and save energy costs.

\section{International Relations}

The FED/EUSA projects need close coordination with the host nation (Korea) and its local Government. One anecdotal example is that of a delay of a high-rise housing project at Yongsan Post, in which the local Government requested a design change (from eight-floor to five-floor) during the bidding stage.

SDD principles also encourage the increased usage of local products, which, however, must conform to the USACE specifications and the safety standards applicable to CONUS construction projects. Further effort is required to identify appropriate local materials and equipment. The future mission of EUSA installlations was briefly discussed during the charrette, but it is the beyond the scope of this report.

\section{Local Environment in Korea}

According to the Energy Information Administration, *

For years, South Korea was one of Asia's fastest growing, most successful economies. This rapid industrialization and growth in income, however, has had environmental impacts.

An anecdotal example of such environmental impacts is the "black carbon filter," a white high-efficiency particulate air (HEPA) filter that became clogged within a couple of months of installation in one family housing unit in Yongsan Post. Land space (especially for Yongsan Post) in Korea is severely limited and at a premium. Yongsan Post is constantly under pressure for relocation. The

\footnotetext{
* Accessible through the Internet at web page: http://www.eia.doe.gov
} 
NIMBY ("not in my back yard") syndrome is already showing up near the potential relocation site.

Another trend, as one charrette attendee observed, is the growth of Korean Government environmental regulations. An incidence of ill-prepared wastewater disposal was a hot topic in the local media, which closely observes and reports on environmental incidents. Requirement of the "environmental impact statement" for FED/EUSA projects would be a costly regulation in time and dollars. Therefore, the SDD approach for every FED/EUSA project is recommended not only to make EUSA installations environmentally sustainable, but also to avoid future conflicts with the host country and to conserve U.S. resources.

\section{JP-8 Fuel for Space/DHW Heating}

Currently, JP-8 oil is used for space and DHW heating in EUSA installations in Korea. Table 2 shows the energy consumption and cost for the EUSA installations in FY00. Note the limited choice of fuels in facility operation.

Table 2. EUSA FYO0 energy consumption and cost.

\begin{tabular}{|l|c|c|}
\hline Energy Type & Energy Consumption & Energy Cost $^{*}$ \\
\hline Electricity & $32 \%$ & $53 \%$ \\
\hline JP-8 & $68 \%$ & $47 \%$ \\
\hline Natural Gas & $0.2 \%$ & $0.2 \%$ \\
\hline${ }^{*}$ FY00 Utility bill total $=\$ 39,397,439$ \\
\hline
\end{tabular}

Natural gas line is readily available for Yongsan Post and Camp Casey. Natural gas has a number of desirable characteristics compared to the JP-8 fuel. Most of the advanced facility energy systems require natural gas for the fuel source. Examples include fuel cell, micro-turbine distributed generation system, and natural gas cooling systems. JP-8 fuel is also a source of potential environmental impact in air quality as well as soil/water contamination due to potential leaks. A detailed feasibility analysis of choice of fuel for EUSA installations in Korea is beyond the scope of this report. However, an option study for the replacement of JP-8 oil with natural gas for space/DHW heating is recommended. 


\section{Summary and Recommendations}

\section{Summary}

This work has documented the proceedings of the SDD charrette at FED. The charrette was well represented by the engineers, architects, master planners, and managers who serve the EUSA installations in Korea. The data generated serve to define and provide a current "snapshot" view of the issues confronting FED/EUSA installations in Korea in 2002. Field professionals across the Korean Peninsula presented a wide range of issues in six categories:

1. Water

2. Energy

3. Materials/Resources

4. Indoor Environmental Quality (IEQ)

5. Facility Delivery

6. Sites/Future Missions.

These issues were collimated and prioritized. For each priority issue, a desired end state (goal) was defined, metrics were defined, a timeframe was developed, and the first two steps toward the goal were recommended. The information in this report will serve as a baseline reference for the field engineers and planners for project development. It will also serve as the year 2002 benchmark to gauge the progress in the infrastructure improvement for the EUSA installations in Korea.

A number of issues unique to FED/EUSA were discussed in this report:

- limited project span (up to $5 \mathrm{yr}$ )

- international relations

- local environmental conditions (severely limited space and ambient air pollution)

- limited fuel choice available to EUSA installations (especially the use of JP-8 fuel for space and domestic water heating).

Fully implemented SDD principles in FED/EUSA project planning, design, construction, and operation will be the key to successful resolution of not only the local unique issues, but also the general issues identified during the 3-day charrette in Korea. 


\section{Recommendations}

This charrette recommended that efforts be made to reach specific goals in each of six areas, including two specific steps to begin achieving each goal:

1. Water

a. Water goals include:

(1) Plan and implement a sustainable water conservation program.

(2) Plan and implement a water recycle/reuse program.

(3) Educate population on the need/methods to conserve water.

(4) Use central wash racks that use nonpotable/recycled water/remove wash racks from maintenance areas.

(5) Use water efficient fixtures.

b. The first two steps to begin achieving these goals are:

(1) Provide water filters to potable water faucets.

(2) Need to have on going pipe replacement program to replace with best available product. PVC? CPVC? Less corrosive.

2. Energy goals include:

a. Plan and implement sustainable energy program-increase and "fence" energy funding. The first two steps to begin achieving these goals are:

(1) Complete all lighting upgrades by 2005.

(2) Replace all single-pane windows with double-pane windows by 2008.

b. Diversify energy supply options for fixed facilities-minimize JP-8 pollution, the first two steps of which are:

(1) Identify alternative sustainable fuel sources and perform economic analysis.

(2) Estimate implementation costs of sustainable alternative.

c. Implement energy codes applicable to local facilities, based on nationally accepted guidelines, the first two steps of which are:

(1) Modify and adopt accepted various national energy codes, for local conditions.

(2) Implement adopted energy codes.

3. Materials/Resources goals include:

a. Acquire the majority (90 percent) of products (based on costs) locally.

b. Establish a dedicated office to research and find more locally manufactured, U.S. acceptable products.

c. Establish access to locally manufactured OEM products.

4. Indoor Environmental Quality goals include:

a. New and retrofit buildings meet IAQ/ATFP standards, with respect to local meteorological conditions, and verification that IAQ/ATFP standards 
are being met is included as part of the building commissioning/recommissioning process, the first two steps of which include:

(1) Review existing IAQ/ATFP standards and increase awareness of these issues to occupants.

(2) Incorporate IAQ/ATFP standards in design, construction and commissioning processes.

b. To maintain new/retrofitted heating, ventilation, and air conditioning (HVAC) equipment, so that proper IAQ/ATFP standards continue to be met, including circulation, humidity, and filtration, the fist two steps of which include:

(1) Secure funding and workforce to perform effective HVAC system maintenance.

(2) Provide technical manuals and training to workforce for preventive maintenance.

5. Facility Delivery goals include:

a. Create a 25-year vision that clearly defines the intent and financial commitment to provide pleasant, sustainable, and modern/upgraded Army facilities for Army troops, families, and civilian workers.

b. Effectively coordinate with local Korean cities/governmental agencies to ensure cooperation, transparency, trust, and smooth project delivery, the first two steps of which are:

(1) Share the Command Vision with installations, FED, and other appropriate agencies.

(2) Ensure that the Installation Master Plans clarify the command vision.

c. Work to achieve the most efficient, reliable contracting method, the first two steps of which are:

(1) Make sure contractors are prequalified so they can be hired using the best value contracting method.

(2) CCK needs to consider having prequalified bonded contractors.

d. Establish the project delivery team early to ensure customer satisfaction when facility construction/renovation is completed, commissioned, and accepted.

e. Fund and enable project team members to participate in project delivery during entire project life, the first two steps of which are:

(1) Develop the role of the project delivery team for each phase, including funding. (Standardize the procedure; Consider Design/Build projects-then it is really important to have charrette and a welldeveloped 1391/scope).

(2) Hold a Charrette with the project delivery team to fully develop the 1391. 
6. Sites/Future Missions

a. Sites/Future Missions goals are:

(1) Relax nonperimeter force protection guidelines with a more concentrated effort focused at entries, perimeters, and key facilities.

b. The first two step to begin achieving these goals are:

(1) Fully explore the ATFP alternatives to minimize impact on sustainable development and operational efficiencies.

(2) Document the cost of applications of ATFP actions relative to the gain or loss of protection.

7. It is also recommended that the identified SDD goals and recommendations will be incorporated into the EUSA installation design guide currently under development. 


\section{References}

Anderson, Ray, Midcourse Correction: Towards a Sustainable Enterprise: The Interface Model (The Peregrinzella Press, Atlanta, GA, 1998).

Atkisson, Alan, Believing Cassandra: An Optimist Looks at a Pessimist's World (Chelsea Green Publishing, 1999).

Camp Casey website, URL: http://www-area1.korea.army.mil/installations/cpcasey.htm

Executive Order (EO) 13148, "Greening the Government Through Leadership in Environmental Management” (12 April 2000).

EO 13101, "Greening the Government through Waste Prevention, Recycling, And Federal Acquisition" (14 Sept 1998).

EO 13123, "Greening the Government through Efficient Energy Management” (03 June 1999).

EO 13134, "Developing and Promoting Biobased Products and Bioenergy" (12 August 1999).

EO 13148, "Greening the Government Through Leadership in Environmental Management" (22 April 2000).

EO 13149, "Greening the Government through Federal Fleet and Transportation Efficiency" (21 April 2000).

Eady, D., R. Tschirhart, J. Vanegas, and R. Webster, "Searching for Installation Sustainability in an Encroaching and Transforming World", NDIA Conference (Charleston, SC, April 2002), available through the Internet at URL: http://www.cecer.army.mil/EARUpdate/NLFiles/2002/AEPISustainWP22April02.doc

Hawken, Paul, The Ecology of Commerce: A Declaration of Sustainability, HarperBusiness Press, 1993.

Jones, D., M. Messenger, R. Webster, and R. Stine, "Installation Sustainability: Transforming the Army's Future,” Federal Facilities Environmental Journal (Spring 2002).

Keysar, E., R. Webster, and A. Steinemann, "Integrating NEPA with Master Planning: Lessons From the U.S. Army," Environmental Impact Assessment Review (In publication, 2002).

SPiRiT Guide for Army Garrison Commanders, Facility Planners and Project Delivery Teams, available through the Internet at URL: http://www.hqda.army.mil/acsimweb/fd/docs/FinalSPiRiTUpdate31May02.pdf 
Sustainable Federal Facilities: A Guide to Integrating Value Engineering, Life-Cycle Costing, and Sustainable Development (2001), available through the Internet at URL:

http://www.nap.edu/catalog/10093.html

Sustainable Planning, A Multi-Service Assessment (1999), available through the Internet at URL: https://www.denix.osd.mil/denix/Public/Library/Sustain/assessment99.pdf

Army Regulation (AR) 200-2, Environmental Analysis of Army Actions (Headquarters, Department of the Army [HQDA], March 2002).

U.S. Army Corps of Engineers, USACE Environmental Operating Principles and Implementation Guidance (2001).

U.S. Army Engineer Research and Development Center (ERDC) Sustainable Design and Development website, available through the Internet at URL: http://www.cecer.army.mil/SustDesign

U.S. Marine Corps, A Model for Sustainable Environmental Management (Marine Corps Base, Camp Lejeune, NC, 1999), available through the Internet at URL:

https://www.denix.osd.mil/denix/Public/Library/EMS/Documents/camplejunebooklet.pdf 


\section{Appendix A: SDD Policy Memorandum (18 Mar 02) from ASA(I\&E) to MACOM Commanders}




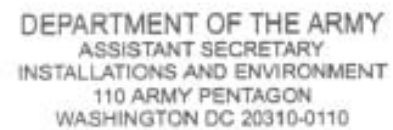

18 MAR 2002

MEMORANDUM FOR SEE DISTRIBUTION

SUBJECT: Sustainable Design and Development

Leading architects, builders, and customers are designing and constructing innovative, environmentally compatible, energy efficient, and people-friendly buildings through a process known as sustainable design and development (SDD).

The Army has adopted the Sustainable Project Rating Tool (SPiRiT) scoring and rating process to characterize the sustainability of a building on a bronze, silver, gold, and platinum scale. All buildings designed and constructed after June 2001 should achieve a bronze rating, with select showcase projects identified to achieve gold and platinum ratings.

I am convinced that this process is an excellent method for improving the quality of the facilities we build to support readiness, training, and soldier wellbeing. Therefore, I ask your personal support to make this initiative a success. I have asked the Chief of Engineers and Assistant Chief of Staff for Installation Management to report back to me on actions being taken to incorporate sustainability into your construction projects. I would also be interested in any particular ideas or experiences that you may have had in implementing this program.

Information on SDD documents and SPIRIT is available on the web at http://www hada.army. mil/acsimweb/fd/linksSDD. htm and http//www cecer army. mil/sustdesign.

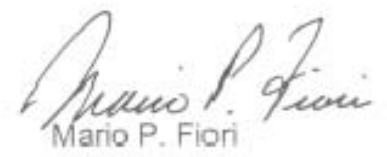

Printed on Racyclod Paper 
DISTRIBUTION:

COMMANDER

US ARMY EUROPE AND SEVENTH ARMY

US ARMY FORCES COMMAND

US ARMY MATERIEL COMMAND

US ARMY TRAINING AND DOCTRINE COMMAND

US ARMY MILITARY DISTRICT OF WASHINGTON

US ARMY CORPS OF ENGINEERS

US ARMY MEDICAL COMMAND

US ARMY PACIFIC

EIGHTH US ARMY

US ARMY TEST AND EVALUATION COMMAND

US ARMY RESERVE COMMAND

US ARMY SOUTH

US ARMY INTELLIGENCE AND SECURITY COMMAND

US ARMY SPECIAL OPERATIONS COMMAND

US ARMY SPACE AND MISSILE DEFENSE COMMAND

US ARMY CRIMINAL INVESTIGATION COMMAND

MILITARY TRAFFIC MANAGEMENT COMMAND

SUPERINTENDENT

US MILITARY ACADEMY

US ARMY NATIONAL GUARD 


\section{ACSIM Memo describing the Sustainable Project Rating Tool (SPiRiT)}

As of 1 June 2001, Army activities will begin using SPiRiT to evaluate sustainability for construction and repair projects. The initial Army goal is for all projects to reach the Bronze level.

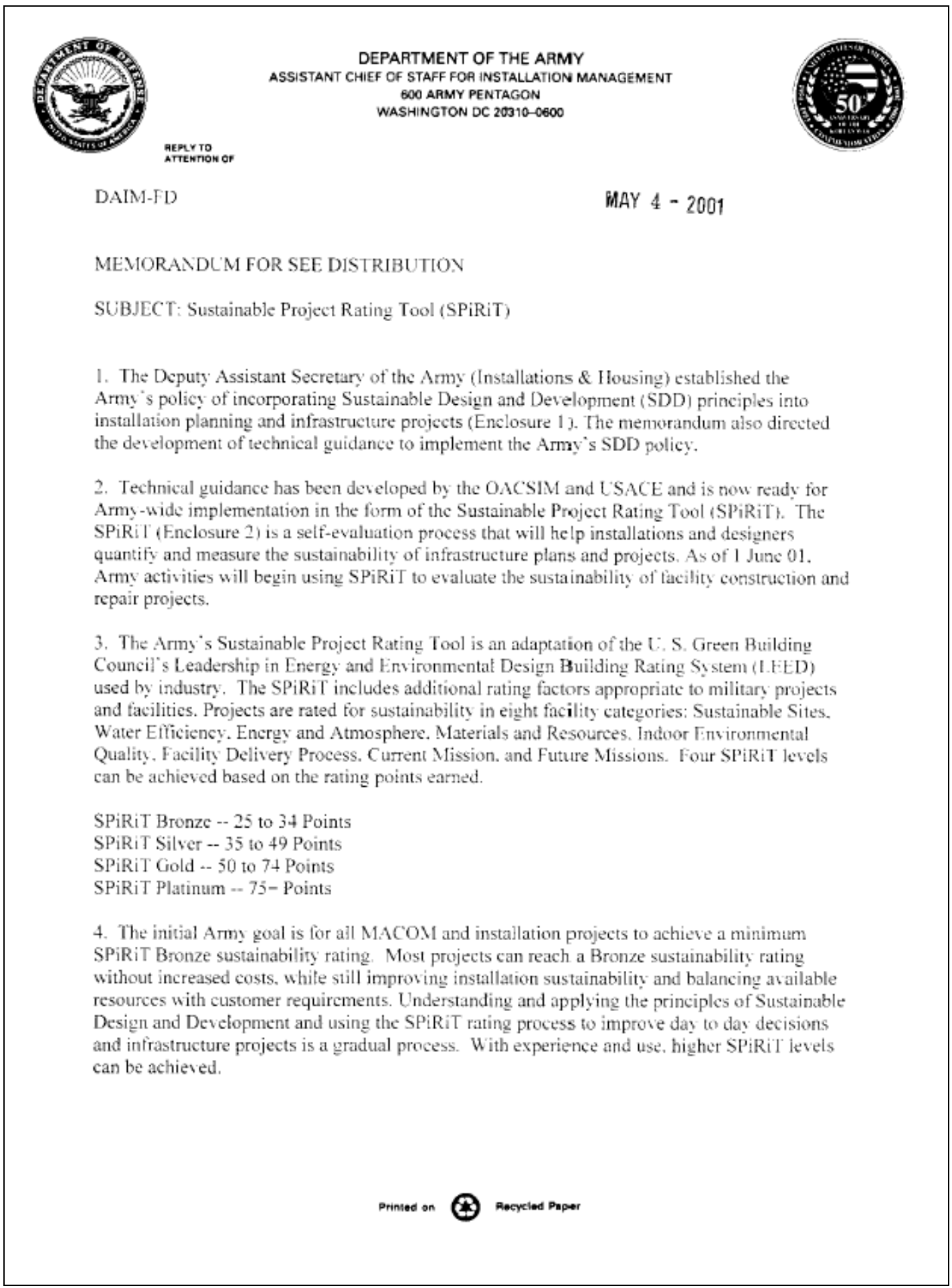


DAIM-FD

SUBJECT: Sustainable Project Rating Tool (SPiRiT)

5. HQ USACE will provide additional implementing instructions for using SPiRiT in the construction project design and execution process. Current plans are to designate several MILCON projects each year as SDD Showcase Projects. All activities are encouraged to designate their own SDD Showcase Projects and strive for higher SPiRiT levels of Gold or Platinum.

6. Over the past ten months, District Engineers and Installation DPWs have become familiar with the sustainable rating process through the USACE conducted SDD training workshops. Use of SPiRiT supports Army poticy to adopt sustainable design and development and provides the technical guidance for measuring the sustainable characteristics of installation plans and infrastructure projects. For additional SDD-related and SPiRiT information see OACSTM and USACE web-sites at http:/www.hqda.amy.mil/acsimweb/fd/inksSDD.htm and bttp:/www cecerarmy.mil/sustdesign, Recommend you give this information broad distribution among your installations.

7. My POC on this action is Mr. John Schar1 (DAIM-FDF, DSN 328-7614; CML 703-4287614 e-mail jolm.scharlachoda.army.mil).

2 Encls

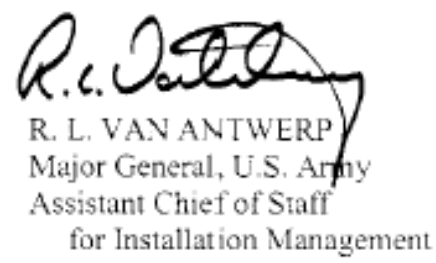

DISTRIBUTION:

COMMANDER

US ARMY EUROPE AND SEVENTH ARMY, ATTN: AEAGX, AEAEN-EH, APO $\mathrm{AE}, 09014$

US ARMY FORCES COMMAND, ATTN: FCCS, AFPI-EN, FORT MCPHERSON, GA 30330-6000

US ARMY MATERIEL COMMAND, ATTN: AMCCS, AMCEN, ALEXANDRIA, VA 22333-0001

US ARMY TRAINING AND DOCTRINE COMMAND, ATTN: ATCS, ATBO-G, FORT MONROE, VA $23651-5000$

US ARMY MILITARY DISTRICT OF WASHINGTON, ATTN: ANCS, ANEN, FORT

LESLEY J. MCNAIR, WASHINGTON, DC 20319-5050

US ARMY CORPS OF ENGINEERS, MILITARY PROGRAMS, ATTN: CECG, CELD-ZE, CEMP, ISD, 441-GSTREET, NW, WASHINGTON DC 20314-1000

ARMY MEDICAL COMMAND, ATTN: MCCG, HSCS, FORT SAM HOUSTON, TX $78234-6000$ 
DAIM-FD

SUBJECT: Sustainable Project Rating Tool (SPiRiT)

DISTRIBLTION (CONT)

US ARMY PACFFIC, ATTN: APLG, APLG-PM, FORT SHAFTER, HI 96858-5100

EIGHTH US ARMY, ATTN: FKCS, EAEN, APO AP 96204-0078

US ARMY TEST \& EVALUATION COMMAND, ATTN: CSTE, CSTE-ILE-EH, 4501 FORD AVENLE, ALEXANDRIA, VA 22302-1458

US ARMY RESERVE COMMAND, ATTN: AFRCS, DAAR-EN, 3800 NORTH CAMP

CREEK PARKWAY, SW, ATLANTA, GA 30331-5099

L'S ARMY SOUTH, ATTN: SORM, SOCS, DCSRM, APO AA 34004-5000

US ARMY INTELLIGENCE \& SECURITY COMMAND, ATTN: OACS, 8825 BELLAH STREET, FORT BELVOIR, VA 22060-5246

US ARMY SPECIAL OPERATIONS COMMAND, ATTN: AOCS, AOEN, FORT BRAGG, NC 28307-5212

US ARMY SPACE AND MISSILE DEFENSE COMMAND, ATTN: CSCS, CSMD-EN. HLNSTVILLE, AL 35807-3801

US ARMY CRLMINAL INVESTIGATION COMMAND, ATTN: CFG-CX, CESP-EN, ABERDEEN PROVING GROUND MD 22041-5015

MILITARY TRAFFIC MANAGEMENT COMMAND, ATTN: MTCS, MT-PAL, 5611

COLL'MBIA PIKE, FALLS CHURCH, VA22041-5050

SUPERTNTENDENT

US MILITARY ACADEMY, ATTN: MACS, MAEN, WEST POINT NY 10996-1592

CHIEF

US ARMY NATIONAL GUARD, ATTN: NGB-CS, NGB-ARI, $111 \mathrm{~S}$. GEORGE MASON DRIVE. ARLINGTON, VA 22204

CF:

DEPUTY ASSISTANT SECRETARY OF THE ARMY (INSTALLATIONS \& HOUSING). OASA(I\&E)

DIRECTOR

US ARMY CONSTRUCTION ENGINEERING RESEARCH LABORATORY. CHAMPAIGN, IL 61820

US ARMY CORPS OF ENGINEERS, ENGINEERING AND SUPPORT CENTER HUNTSVILLE, ATTN: CEHNC-DE, HUNTSVILLE, AL 35807-4301

DEFENSE LOGISTICS AGENCY, ATTN: MMBI, 8755 JOHN J. KNGMAN ROAD, FORT BELVOIR, VA 22060

DAIM-FDC

DAIM-FDH

DAIM-CSO

DAIM-ED

DAIM-MD

DAIM-ZR

CFSC 


\section{USACE Memo directing the use of SPiRiT}

This 1 June 2001 memorandum directs the use of SPiRiT for all new design, and for ongoing projects to the extent possible. It also notes USACE membership on the U.S. Green Building Council.

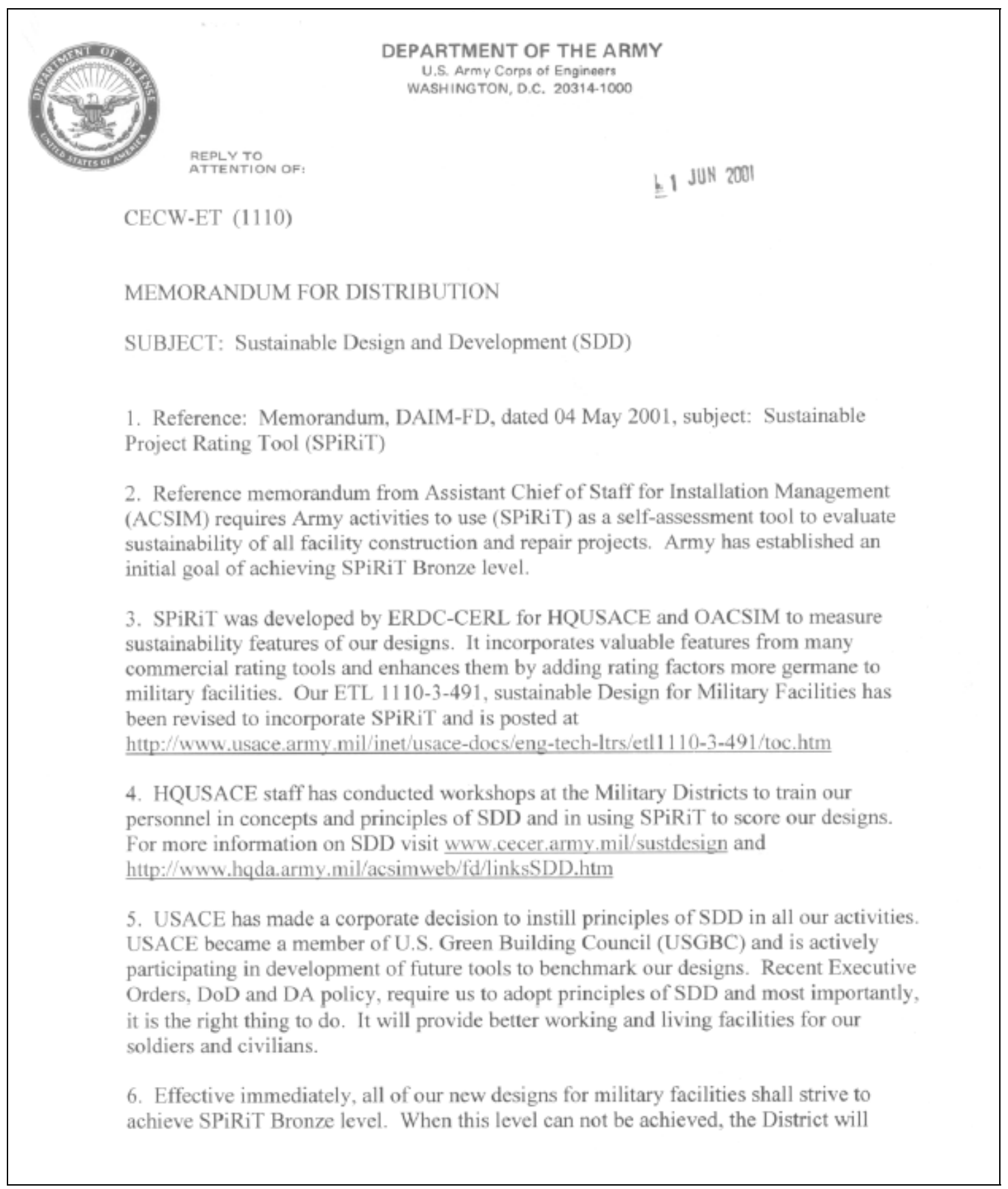


CECW-ET (1110)

Subject: Sustainable Design and Development (SDD)

inform MSC and HQUSACE in accordance with ETL 1110-3-491. To the extent possible, Districts are strongly encouraged to phase in SPiRiT into the ongoing design.

7. My Point of Contact for this action is Mr. Harry Goradia, CECW-ET, 202-761-7170.

Encl

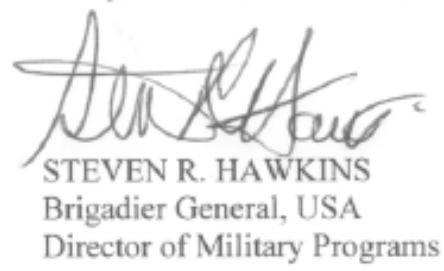

DISTRIBUTION:

Commander, Great Lakes and Ohio River Division

Commander, Mississippi Valley Division

Commander, North Atlantic Division

Commander, Northwestern Division

Commander, Pacific Ocean Division

Commander, South Atlantic Division

Commander, South Pacific Division

Commander, Southwestern Division

Commander, Huntsville Engineering and Support Center

Commander, Transatlantic Programs Center

Director, ERDC

CF:

Commander, Alaska District

Commander, Albuquerque District

Commander, Baltimore District

Commander, Buffalo District

Commander, Charleston District

Commander, Chicago District

Commander, Detroit District

Commander, Fort Worth District

Commander, Galveston District

Commander, Honolulu District

Commander, Huntington District

Commander, Jacksonville District

Commander, Kansas City District

Commander, Little Rock District 
CECW-ET (1110)

Subject: Sustainable Design and Development (SDD)

Copy Furnished: Continued

Commander, Los Angeles District

Commander, Louisville District

Commander, Memphis District

Commander, Mobile District

Commander, Nashville District

Commander, New England District

Commander, New Orleans District

Commander, New York District

Commander, Norfolk District

Commander, Omaha District

Commander, Philadelphia District

Commander, Pittsburgh District

Commander, Portland District

Commander, Rock Island District

Commander, Sacramento District

Commander, St. Louis District

Commander, St. Paul District

Commander, San Francisco District

Commander, Savannah District

Commander, Seattle District

Commander, Tulsa District

Commander, Vicksburg District

Commander, Walla Walla District

Commander, Wilmington District 


\section{CERL Distribution}

Chief of Engineers

ATTN: CEMP-IS/Installation Support Div.

ATTN: CEMP-ET (2)

ATTN: CEHEC-IM-LH (2)

Assistant Chief of Staff for Installation Management (ACS[IM])

ATTN: DAIM-FDF-VE

Commander, USACE Far East District

ATTN: CEPOF-ED-DA/34th Support Group

ATTN: DPW

Engineer Research and Development Center (Libraries)

ATTN: ERDC, Vicksburg, MS

ATTN: Cold Regions Research, Hanover, NH

ATTN: Topographic Engineering Center, Alexandria, VA

Defense Tech Info Center 22304

ATTN: DTIC-O

11

$6 / 02$ 


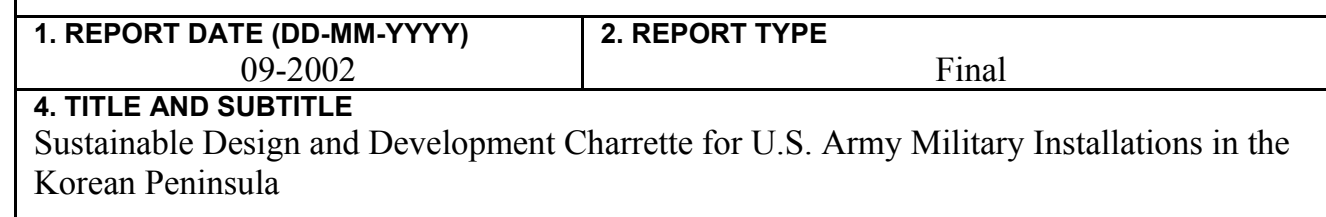

Korean Peninsula
3. DATES COVERED (From - To)

5a. CONTRACT NUMBER

5b. GRANT NUMBER

5c. PROGRAM ELEMENT NUMBER

5d. PROJECT NUMBER

MIPR

5e. TASK NUMBER

CFE

5f. WORK UNIT NUMBER

G42

8. PERFORMING ORGANIZATION REPORT NUMBER

ERDC/CERL TR-02-24
7. PERFORMING ORGANIZATION NAME(S) AND ADDRESS(ES)
U.S. Army Engineer Research and Development Center (ERDC)

Construction Engineering Research Laboratory (CERL)

PO Box 9005

Champaign, IL 61826-9005

\section{SPONSORING / MONITORING AGENCY NAME(S) AND ADDRESS(ES)}

U.S. Army Corps of Engineers

Far East District

Unit 15546

APO AP 96205-0610
10. SPONSOR/MONITOR'S ACRONYM(S)

CEPOF-ED-DA

11. SPONSOR/MONITOR'S REPORT NUMBER(S)

12. DISTRIBUTION / AVAILABILITY STATEMENT

Approved for public release; distribution is unlimited.

\section{SUPPLEMENTARY NOTES}

Copies are available from the National Technical Information Service, 5285 Port Royal Road, Springfield, VA 22161.

\section{ABSTRACT}

U.S. Army Corps of Engineers (USACE) Districts are required to begin incorporating sustainable design and development (SDD) principles into their projects. To meet the requirements, the USACE Far East District (FED) has begun SDD training for its engineers and customers with the Eighth U.S. Army (EUSA) installations in Korea. As a part of this training, FED conducted an SDD charrette 2628 February 2002. This report documents the proceedings of the SDD charrette at FED that provided a current "snapshot" view of the issues confronting FED/EUSA installations in Korea in 2002 in six categories: (1) Water, (2) Energy, (3) Materials/Resources, (4) Indoor Environmental Quality (IAQ), (5) Facility Delivery, and (6) Sites/Future Missions. For each priority issue, a desired end state (goal) was defined, metrics were defined, a timeframe was developed, and the first two steps toward the goal were recommended.

\section{SUBJECT TERMS}

Sustainable Design and Development (SDD)

Sustainable Project Rating Tool (SPiRiT)

\section{SECURITY CLASSIFICATION OF:}

\section{a. REPORT}

Unclassified

\section{b. ABSTRACT} Unclassified
Korea

installation design
17. LIMITATION
OF ABSTRACT

c. THIS PAGE

Unclassified
SAR sustainable facilities

energy efficient

\begin{tabular}{|c|c|}
\hline $\begin{array}{c}\text { 18. NUMBER } \\
\text { OF PAGES }\end{array}$ & $\begin{array}{c}\text { 19a. NAME OF RESPONSIBLE PERSON } \\
\text { Chang W. Sohn }\end{array}$ \\
\cline { 2 - 2 } 59 & $\begin{array}{c}\text { 19b. TELEPHONE NUMBER (in- } \\
\text { clude area code) }\end{array}$ \\
& (217) $373-6739$
\end{tabular}

